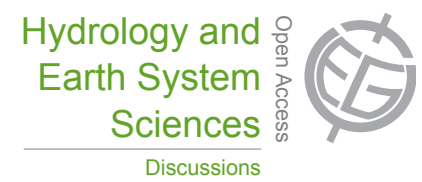

This discussion paper is/has been under review for the journal Hydrology and Earth System Sciences (HESS). Please refer to the corresponding final paper in HESS if available.

\title{
A coupled distributed hydrological-stability analysis on a terraced slope of Valtellina (northern Italy)
}

\section{Camera ${ }^{1,2}$, T. Apuani ${ }^{1}$, and M. Masetti ${ }^{1}$}

${ }^{1}$ Università degli Studi di Milano - Dipartimento di Scienze della Terra "A. Desio", Milano, Italy ${ }^{2}$ The Cyprus Institute - Energy, Environment and Water Research Center, Nicosia, Cyprus

Received: 4 February 2013 - Accepted: 5 February 2013 - Published: 21 February 2013 Correspondence to: C. Camera (c.camera@ cyi.ac.cy)

Published by Copernicus Publications on behalf of the European Geosciences Union.

\section{HESSD}

$10,2287-2322,2013$

\section{A coupled \\ distributed \\ hydrological-stability analysis \\ C. Camera et al.}

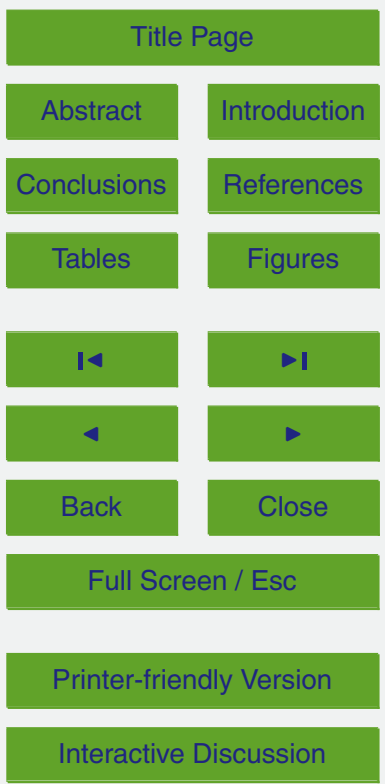




\section{Abstract}

The aim of this work was to understand and reproduce the hydrological dynamics of a slope, which was terraced using dry-stone retaining walls and its response to these processes in terms of stability at the slope scale. The slope studied is located in Valtel-

5 lina (northern Italy), near the village of Tresenda, and in the last $30 \mathrm{yr}$ has experienced several soil slip/debris flow events. In 1983 alone, such events caused the death of 18 people. Direct observation of the events of 1983 enabled the principal triggering cause of these events to be recognized in the formation of an overpressure at the base of a dry-stone wall, which caused its failure.

10 To perform the analyses it is necessary to include the presence of dry-stone walls, considering the importance they have in influencing hydrological and geotechnical processes at the slope scale. This requires a very high resolution DEM $(1 \mathrm{~m} \times 1 \mathrm{~m}$ because the walls are from $0.60 \mathrm{~m}$ to $1.0 \mathrm{~m}$ wide) that has been appositely derived. A hydrogeological raster-based model, which takes into account both the unsaturated and sat15 urated flux components, was applied. This was able to identify preferential infiltration zones and was rather precise in the prediction of maximum groundwater levels, providing valid input for the distributed stability analysis. Results of the hydrogeological model were used for the successive stability analysis. Sections of terrace were identified from the downslope base of a retaining wall to the top of the next downslope retaining wall. Within each section a global method of equilibrium was applied to determine its safety factor. The stability model showed a general tendency to overestimate the amount of unstable areas. An investigation of the causes of this unexpected behavior was, therefore, also performed in order to progressively improve the reliability of the model.

\section{Introduction}

Landslides occur worldwide and constitute a serious source of danger, causing environmental damage as well as substantial human and financial losses (EM-DAT, 2010).

\section{HESSD}

10, 2287-2322, 2013

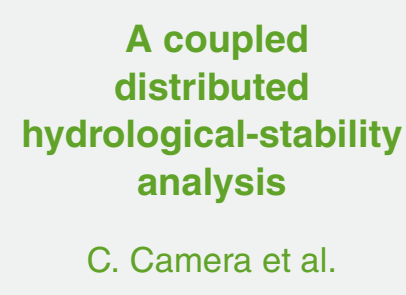

Title Page

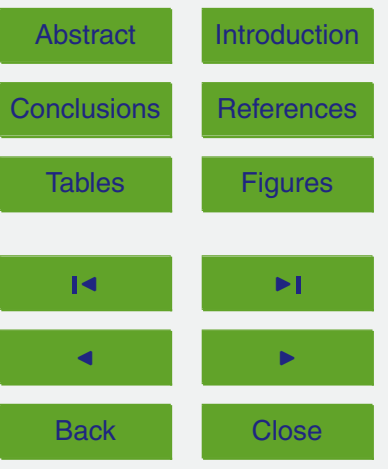

Full Screen / Esc

Printer-friendly Version

Interactive Discussion 
Landslides involve a broad variety of triggering factors, including heavy rainfall, earthquakes, human activity, and predisposing conditions that include geological and geomorphological factors which can themselves be strongly influenced by human activities. In many mountainous areas the presence of a terraced slope is the strongest 5 evidence of a human-modified geomorphological context that has an important influence on slope stability.

The aim of this work is to understand and reproduce the hydrogeological dynamics of a slope subject to instability phenomena and whose peculiarity is being terraced by dry-stone retaining walls.

10 The importance of this work is underlined by the history of the particular terraced slope under investigation, above the village of Tresenda in the central Valtellina (northern Italy), and in general by events occurring on the terraced slopes of the entire valley. During the period of extreme and prolonged rainfalls that affected Valtellina in May 1983, July 1987, November 2000, and November 2002 respectively (Cancelli and 15 Nova, 1985; Crosta et al., 2003, Quan Luna et al., 2010; Blahut et al., 2012), the worst affected areas were slopes on the northern flank of the valley between Sondrio and Tirano that were terraced using dry-stone retaining walls.

In recent years, many studies have investigated the proneness to landslide of the central part of Valtellina, analyzing the problem at different scales and from different point of view. At medium scales (1:25000 to $1: 50000)$, susceptibility maps were constructed (Blahut et al., 2010a) and validated (Sterlacchini et al., 2011), and a hazard assessment was also developed (Blahut et al., 2010b). The following natural step was to develop a risk assessment at a more detailed scale. The soil slip/debris flow event that occurred in Selvetta in July 2008, permitted vulnerability curves to be reconstructed (Akbas et al., 2009; Quan Luna et al., 2011). This output was later applied by Quan Luna et al. (2013) to a possible risk scenario in Tresenda, recognized by Blahut et al. (2012). It was defined by combining a database of historical events and the topographical characteristics of the area under examination, but not by considering the physics of the hydrogeological and geotechnical processes that lead to the triggering

\section{HESSD}

10, 2287-2322, 2013
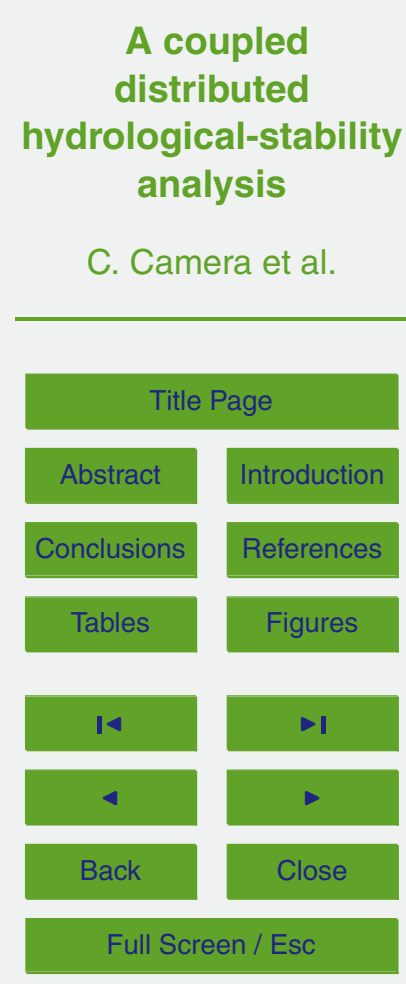

Printer-friendly Version

Interactive Discussion 
of the superficial landslide. The slope uphill of Tresenda is characterized by the presence of numerous dry-stone walls, which is a further complication. However, Camera et al. $(2012 a, b)$ analyzed the influence that the presence of terraces retained by drystone walls have on both hydrogeological processes and slope stability at a very de5 tailed scale (single terrace). The aim of this study is to expand the analyses to a slope scale in order to detect possible superficial landslide source areas, considering the presence of dry-stone walls and the physics of the processes involved.

Many works have investigated slope stability at large scales. The most common method used is the infinite slope stability method (e.g. Schmidt et al., 2008; Ray et al., 10 2011; Montrasio et al., 2012; Segoni et al., 2012). However, in our particular geomorphological context the stability problem cannot be solved with the distributed application of the infinite slope stability method given the presence of certain factors: the length of the single cell is too small to be considered much higher than the depth of the potential sliding surface; there is no parallelism between topographical surface and potential 15 sliding surface; dry stone walls cause abrupt changes in slope morphology that cannot be taken into account in the method; and furthermore, the main focus is on the stability of whole terraces and not of the single cell.

In this work we used a coupled hydrogeological-stability model developed in a raster GIS environment with an implemented programming language for environmental dynamic analysis. The hydrogeological model allows the formation of local Perched Groundwater Tables (PGTs) to be evaluated through a simplified unsaturated-saturated groundwater flow analysis. A specific procedure to recognize sections of terrace constituted by a number of cells was used and a global method of equilibrium was applied to determine the safety factor along each section, consistent with the results obtained

\section{HESSD}

10, 2287-2322, 2013

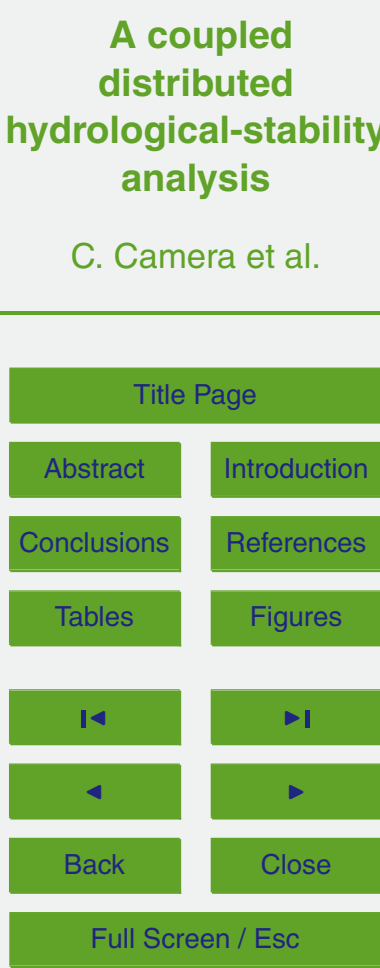

Printer-friendly Version

Interactive Discussion 


\section{Study area}

The study area is located in the central Valtellina, a glacial valley in the Central Alps of northern Italy. The slopes are covered with soils of glacial and colluvial origin that are prone to triggering soil slips and debris flows both on open slopes and in channels.

5 The bedrock consists of a fine-grained schist belonging to the Variscan metamorphic base of the southern Alps (Aprica tectonometamorphic unit) (Gosso et al., 2012), also known as Edolo Schists (Beltrami et al., 1971). Terraced slopes for vineyard cultivation are present on the northern flank in the central section of the valley, covering a surface of $17 \mathrm{~km}^{2}$ (Crosta et al., 2003). The study area of Tresenda is located within this area 10 and is highly representative of many Valtellina terraced slopes. The area has been studied extensively by many authors (Azzola and Tuia, 1983; Cancelli and Nova, 1985; Quan Luna et al., 2010; Blahut et al., 2012; Camera et al., 2012a,b) due to the soil slips/debris flows that caused considerable damage and resulted in human casualties in 1983 and 2002. The slope is under a condition of general instability, as indicated by certain geomorphological evidence such as naturally occurring morphological terraces, with trenches and counter-slopes on the upper part of the slope. Almost the entire slope has been remodeled by a series of anthropogenic terraces created by retaining dry stone walls with heights ranging from 1.4 to $2.5 \mathrm{~m}$. Terrace length and width depend on slope morphological characteristics (slope angle, soil depth and number of bedrock outcrops), but in general their ranges are 20-100 $\mathrm{m}$ in length (along the same elevation contour) and 5-25 $\mathrm{m}$ in width (uphill-downhill). Although the rock substratum is very shallow, few rocky outcrops are present in the area. Mostly, the slope is superficially composed by glacial and colluvial soils; these soils have been used as backfill in the terraces contained by the dry stone walls. A series of paved roads for accessing the vineyards and a drainage system made up of smaller channels contribute to the modification of the natural condition of runoff and infiltration of water from precipitation (Revellino et al., 2008).

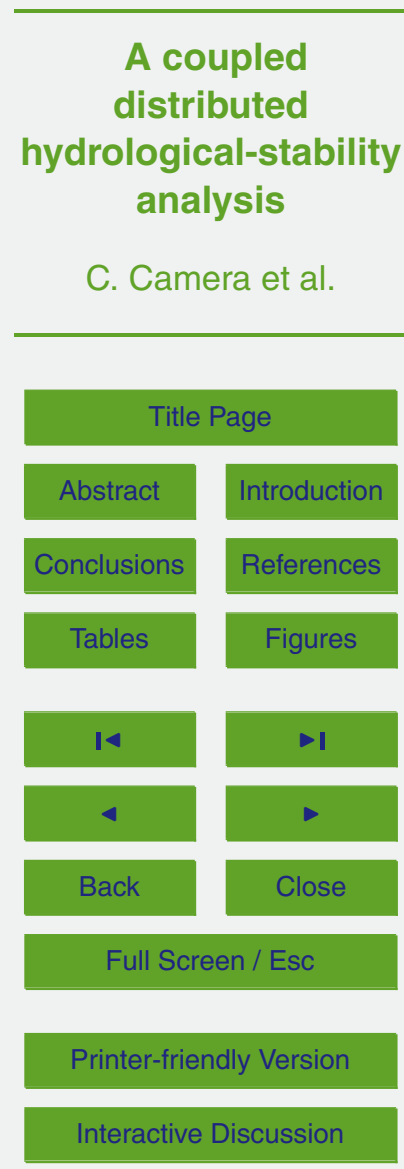


In two previous studies (Camera et al., 2012a,b), the hydrogeological and geotechnical properties of the materials involved, obtained through field and laboratory tests and then used in a first modeling phase performed at the single terrace scale, are accurately presented. In this current study, parameterization of the coupled, distributed, hydrolog5 ical and stability model follows the parameterization of the single-terrace scale models, which can be referred to for further specifications. Here, the parameters of interest are summarized in Table 1; a draining wall is a well-maintained dry-stone wall capable of draining groundwater through voids between the stones whereas a non-draining wall is a poorly maintained dry-stone wall that has progressively lost its groundwater draining

\section{Methods}

In order to perform the analyses it was decided to use a coupled hydrological-stability model developed in a raster GIS environment with an implemented programming language for environmental dynamic analysis (see PcRaster - http://pcraster.geo.uu.nl/ 15 for details and extended references). The physically based coupled models are STARWARS (STorage and Redistribution of Water on Agricultural and Revegetated Slopes) (van Beek, 2002) and SARGLE (SARma Global Limit Equilibrium), which was specifically developed for this case study. SARGLE substitutes PROBSTAB (PROBability of STABility), the original infinite-slope stability model written by van Beek (2002) in combination with STARWARS and already used in different studies (van Beek and van Asch, 2004; Malet et al., 2005; Kuriakose et al., 2009a), where it is possible to find a complete description of both the models' characteristics. The use of physically-based coupled models for the study of the influence of pore water pressure distribution in soils on landslide triggering is widespread in the literature. It is in fact possible to cite several models, SINMAP (Pack et al., 1998), SHALSTAB (Dietrich and Montgomery, 1998), SHETRAN (Ewen et al., 2000), TRIGRS (Baum et al., 2002), and GEOtop-FS (Simoni et al., 2008), and many different studies where such methodology has been applied

HESSD

$10,2287-2322,2013$

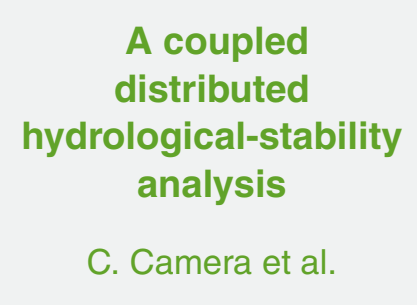

Title Page
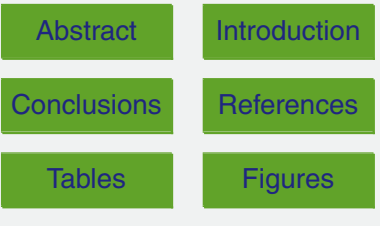

14

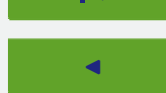

$\rightarrow 1$

Back

$>$

Close

Full Screen / Esc

Printer-friendly Version

Interactive Discussion 
(Angeli et al., 1998; Crosta and Frattini, 2003; Delmonaco et al., 2003; Biavati et al., 2006; Tofani et al., 2006; Meisina and Scarabelli, 2007; Talebi et al., 2008; Cho, 2009).

Compared to these previous studies, the slope of Tresenda has a particular characteristic, represented by the presence of the dry-stone walls. The study area has a lim5 ited extent (about $0.6 \mathrm{~km}^{2}$ ) but, in order to consider the hydrogeological and geotechnical influence of the walls, a great amount of detail is necessary in the resolution of the input raster maps. In particular, besides the environmental, hydrogeological and geotechnical soil characteristics maps, the model must strictly rely on a digital elevation map (DEM) and a soil depth map. Considering that the walls are often between $10 \quad 0.60$ and $1 \mathrm{~m}$ wide, a single pixel dimension of $1 \mathrm{~m} \times 1 \mathrm{~m}$ is required for the raster maps. The procedures adopted for the definition of these high resolution maps, together with their qualities and flaws, are described in the "Soil depth map" section below. Moreover, the presence of the walls does not allow the use of the infinite-slope failure solution, which is widely used in distributed-slope stability analyses.

\subsection{Hydrogeological model}

STARWARS (van Beek, 2002) allows the processes of soil water recharge and groundwater movement to be modeled, taking into account different soil hydrological properties for different recognized land-use classes. The code considers that the quantity of water that can enter the ground in a certain time depends on its availability and on the infiltration capacity of the ground, which is usually defined as a multiple of the saturated hydraulic conductivity, and whose value decreases as the infiltration process continues. Water availability depends on the amount of rainfall and on the losses due to interception by the canopy and evapotranspiration. Once in the ground, water is redistributed through the unsaturated horizon according to its vertical, gravity driven, component of 25 movement calculated on the basis of Richards' equation (Richards, 1931). The horizontal component, which depends on gradients generated by the matrix potential, is considered negligible compared to the vertical component (van Beek, 2002). The unsaturated soil is described through the Soil Water Retention Curve (SWRC), which

\section{A coupled distributed \\ hydrological-stability analysis \\ C. Camera et al.}

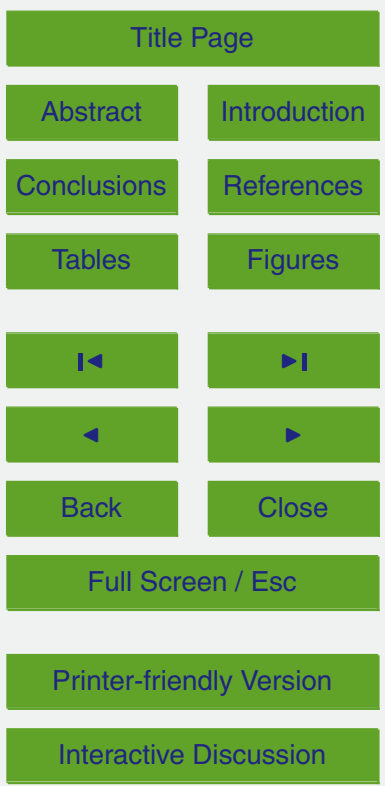

Interactive Discussion 
is defined with the Farrel and Larson (1972) method, and the unsaturated hydraulic conductivity, which is calculated with the Millington and Quirk equation $(1959,1961)$. If the soil lies upon semi-impervious bedrock, when water arrives at the contact point between the two different layers, it may form a perched groundwater table (PGT). If 5 a PGT forms, a saturated component of movement is also considered in the model which depends on the gradient of the water table itself. Water can also move into the bedrock layer, which is considered as a type of infinite reservoir. The model computes the quantity of water that enters into the bedrock layer at each timestep, but does not analyze how it enters. The model considers this water only as bedrock storage. When 10 the available volume of water within a certain cell exceeds the infiltration capacity, it remains on the surface and creates superficial runoff. The superficial runoff is based on the linear drain direction map derived from the DEM but it does not consider the physics of the process. At the end of each timestep calculated by the model, the runoff is in fact moved out of the study area, passing through the recognized superficial out15 let points where a discharge value is calculated. A land use map with seven different classes was drawn and used to provide the input data. In addition, rainfall values taken from gauge data, as well as porosity $(n)$ derived from the laboratory analysis, and saturated hydraulic conductivity $\left(k_{\mathrm{s}}\right)$ obtained after the calibration of the single-terrace scale models (Camera et al., 2012a), were used (Table 1). In order to calculate $k_{\mathrm{s}}$, respective values for a well-maintained and a poorly-maintained wall were used and the modeling results compared. In this phase of the study, urban areas were also considered. It was decided to make the $k_{\mathrm{s}}$ of these urban areas equal to that of soil, but with a very low infiltration capacity, assuming that, under the impermeable asphalt and cement covering, the soil properties are the same. The same reasoning was used for the rocky areas; if soil is present it has the same characteristics as soil of other areas. The infiltration capacity of the walls was lowered compared to that of soil, but by less than that of urban areas. The coefficients of the SWRC model of the Farrel and Larson method (1972), and the input map of the meteorological parameters rainfall and reference evapotranspiration $\left(\mathrm{ET}_{0}\right)$, were kept constant for all areas.

\section{HESSD}

10, 2287-2322, 2013
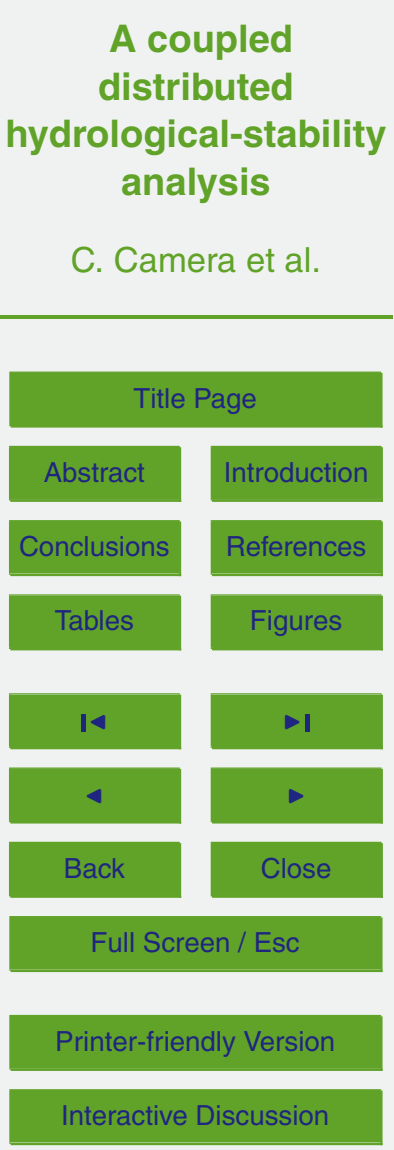


\subsection{Slope stability model}

As already outlined in the previous sections, the distributed application of the infiniteslope stability method could not be applied and therefore PROBSTAB, the original model built in connection with STARWARS, could not be used.

The code was therefore intensively modified, keeping only the definition of certain geometrical properties of the slope and certain general boundary conditions. The first objective was to identify sections along the terraces; each section is formed by the single alignments of the cells comprised between two successive walls including the cell representing the downslope wall. The width of the section corresponds to the width of the cells. The global limit equilibrium method was applied to determine the safety factor of each section. In this context, each cell of the section was assimilated to a single slice in the global limit equilibrium and the failure surface expected to be at the contact point between the soil and the underlying bedrock. For simplicity, the terrace sections were identified along a north-south direction, totaling 17635 within the whole study area. When running the model, only 16441 sections were analyzed as the sections lying on the plain at the top of the study area and those corresponding to the village of Tresenda at the bottom of the valley were excluded. This decision was motivated by the fact that these areas have a very low slope and therefore instability is not expected here. In addition, it allows the very long calculation times to be reduced.

20 Stability was assessed in detail through the Sarma's method (Sarma, 1973). This calculates the critical horizontal acceleration that can lead the mass above the slip surface to the equilibrium state limit, using the horizontal and vertical forces equilibrium equations as well as momentum equilibrium. This critical acceleration is another way of expressing the safety factor; a null critical acceleration corresponds to a traditional safety factor of 1 . The safety factor (FS) can be obtained from the critical acceleration $\left(K_{\text {acc }}\right)$ with an iterative calculation, or through an empirical formula proposed by Sarma and Bhave (1974).

$$
\mathrm{FS}=1.0+3.33 \cdot K_{\mathrm{acc}}
$$

\section{HESSD}

10, 2287-2322, 2013

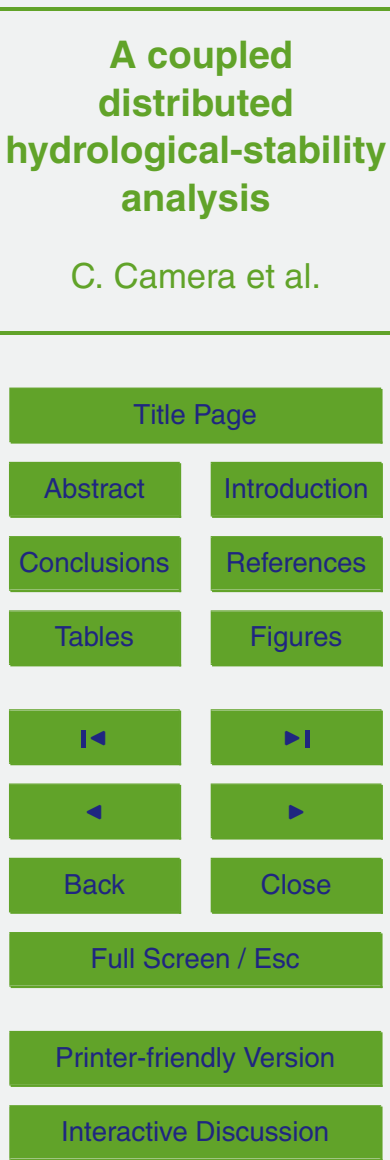


Sarma (1979) modified his method to allow non-vertical and non-parallel boundaries of the different slices to be included in the analysis. This modification is not considered in this study because, working with raster maps, the boundaries of each slice are vertical and parallel.

\section{3.3 DEM and soil depth map}

The definition of the digital elevation model (DEM) and the estimation of the soil depth are of fundamental importance in order to investigate the superficial dynamics of an area affected by the landslide phenomena (Kuriakose et al., 2009b).

\subsubsection{DEM}

10 The DEM was derived using photogrammetric techniques. In particular, aerial photographs from the 2004 flight were used, as they were the most recent, and two adjacent images were sufficient to cover the study areas. Seven, easy to locate, points within the site were initially identified on the photographs and then a GPS survey was carried out to acquire their precise $\mathrm{x}, \mathrm{y}$, and $\mathrm{z}$ coordinates.

15 The photogrammetric interpretation was performed using the RFD evolution ${ }^{\circledR}$ software and resulted in a points cloud with approximately a million points at a resolution of a point every meter. An initial manual cleaning of the data was carried out by visualizing the points cloud in a CAD 3-D environment, which allowed the points that were clearly above or below the topographical surface to be seen, but did not permit a detailed cleaning of the dataset.

The points cloud was therefore imported into a GIS environment. In addition to the points obtained using the photogrammetric analysis, the contour lines of the Regional Topographical Map at a 1:10000 scale and the Comunità Montana Valtellina di Tirano topographical database DB2000 (2003) at a 1:2000 scale were available. In order to obtain the final DEM, it was decided to use only the $1: 2000$ contour lines of the DB2000 where they were available, which is on the valley floor where the village of
HESSD

10, 2287-2322, 2013

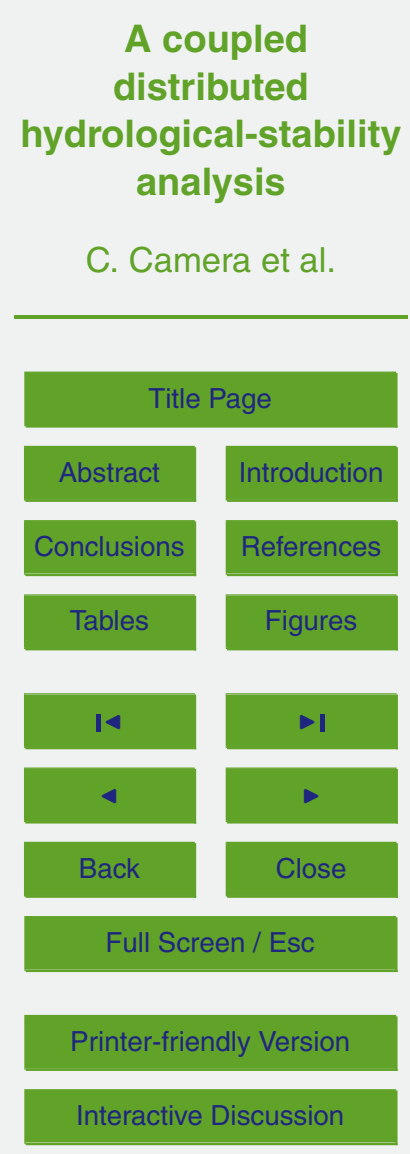

A coupled

gical-stal

analysis

C. Camera et al 
Tresenda lies and in other zones on the slope where houses are present. The photogrammetric derived points for these areas were not considered in the following stages of the study. A DEM with a $2 \times 2 \mathrm{~m}$ resolution, to be compared with the photogrammetric interpretation, was derived from the $1: 10000$ contour lines, where available. This 5 DEM was useful to determine the preciseness of the single photogrammetric points by calculating the difference between the DEM elevation and each point's elevation. A $2 \mathrm{~m}$ resolution was chosen because, although interpolated, it allows a generally quite detailed geometry of the topographical surface to be depicted. The derived $2 \mathrm{~m}$ contour lines appeared to be very irregular so it was decided to edit them manually. This 10 was done by comparing them to the existing 1:10000 contour lines on the digital orthophoto, at the dry-stone wall positions that had previously been identified and digitalized from the orthophoto, and also by considering the urban area contour lines of the DB2000 to which the new elevation contour lines had to be added. The hillshade of the final resulting DEM from the edited contour lines is shown in Fig. 2.

This model is the result of post-processing work on photogrammetric data that required particular morphological difficulties to be addressed, and was performed mostly by the employment of common sense with the only aid being classical CAD and GIS. Finally, even with the lack of more detailed and accurate data, the resulting map was assessed to be an acceptable input for the scale of the subsequent analyses.

\subsubsection{Soil depth map}

Different methods were tested in order to find the best procedure to produce a soil depth map that could take into account the particular morphology of the study area, characterized by the presence of numerous terraces. In particular, various geostatistical techniques were tested and the best result was validated through geo-electrical sur-

veys, which were carried out on a small part of the study area. The final map produced has a resolution of $1 \mathrm{~m} \times 1 \mathrm{~m}$ in order to take into account the presence of dry-stone walls in the area, which have a width of between 0.60 and $1.00 \mathrm{~m}$.

\section{HESSD}

10, 2287-2322, 2013

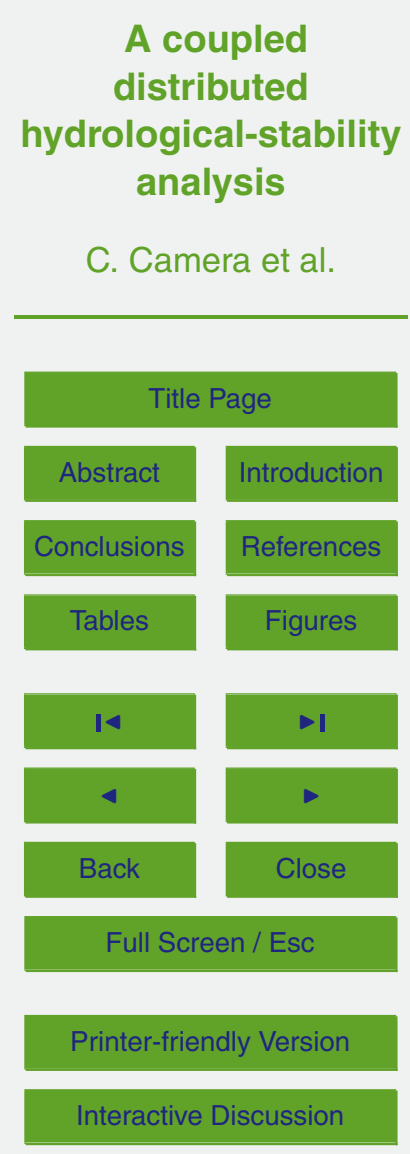

A coupled

distributed

analysis

C. Camera et al. 
At first, it was decided to follow the procedure proposed by Kuriakose et al. (2009b). They used mathematical and geostatistical methods joining environmental copredictors to the variable of interest. They compared different methods, both mathematical and geometrical, such as linear multiple regression using terrain attribute and curvature, wetness index, and distance from streams.

Assuming that the walls might be founded on bedrock or in its proximity, it was decided to use the heights of walls and the distribution of the rocky outcrops as soil depth input data. The final data set comprised 832 samples and was divided into training $(76 \%)$ and test $(24 \%)$ points.

15 In this complicated geomorphological context the techniques already tested by Kuriakose et al. (2009b) were not able to reproduce the expected trend of soil depth. The map obtained with the Block Ordinary Kriging is quite good in terms of the validation indicator values ( $R_{2}$ is 0.38 and Normalized Root Mean Square Error is $\left.15 \%\right)$ but, considering the high variability expected in the soil depth, and the superficial terraced morphology that should be connected with the bedrock geometry, the map appears to be too smooth.

The idea was to add a covariate to the training points that could help maintain the observed morphology and it was therefore decided to perform a co-kriging with training points and a soil depth classes map (Fig. 3a) drawn on the basis of field measurements.

25 The soil depth classes map is intended to be a reinforcement of field measurements only. The variogram model (Fig. 3b) also takes into account the presence of a possible anisotropy in the spatial structure of the measurements. In fact, looking at the map in Fig. $3 a$ it is possible to see how the terraces are aligned along a WSW-ENE direction. In fact, a direction of maximum correlation of $67.5^{\circ}$ (azimuth) was identified. 5 environmental maps (Moore et al.,1993; Odeh et al., 1994; Gessler et al., 1995; McKen- zie and Ryan, 1999; McBratney et al., 2000), and geostatistical approaches such as ordinary kriging (Krige, 1951), regression kriging with environmental maps (Odeh et al., 1994, 1995; Goovaerts, 1999) and stochastic simulations from regression kriging. The environmental variables considered in this work are altitude, land use, slope, aspect,

HESSD

10, 2287-2322, 2013

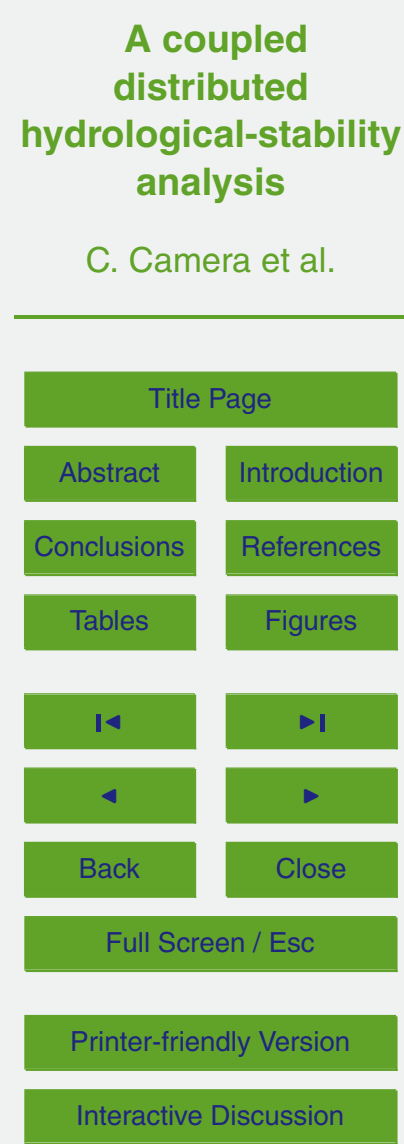

A coupled

gical-stat

.


The use of this technique enabled a very good calibration with the test points to be obtained (Fig. 3d) and also a more variable soil depth, as expected (Fig. 3c).

To further validate the map, not only from a numerical but also from a physical point of view, on a small area of the slope 6 geo-electrical lines parallel to, and 1 line perpendicular to the walls' alignment were drawn. The lines were either 32 or $48 \mathrm{~m}$ long. Then, after the correct topographical positioning of the lines, from the interpretation of the inverse models obtained, it was possible to define a geo-electrical soil depth map. This map was then compared with the geostatistical map in order to individuate and correct areas showing a major difference in the soil depth estimate (Fig. 4a-c).

10 In general, the geostatistical map along the slope tends to underestimate the deepest soils. On the other hand, for soil depth values between 1.0 and $2.0 \mathrm{~m}$, the dispersion of the correspondent values estimated using the geostatistical methods appears to be very low, providing a good quality estimate for this soil depth. This estimate is consistent with the original measurements with which the geostatistical analysis was performed. 15 The dry-stone walls were originally thought to be founded on bedrock or in its proximity, although the geo-electrical surveys show that, in a small number of cases, this is not true, at least within the study area, and it is possible to find $2 \mathrm{~m}$ or more of conductive soil layer under the base of a wall.

Overall, the calculated RMSE and NRMSE of the geostatistical map compared to 20 the geo-electrical map are deemed satisfactory. Considering the high variability of the investigated area, the RMSE and NRMSE values of respectively $0.84 \mathrm{~m}$ and 0.20 can be considered as acceptable.

\section{Discussion and results}

In order to define potential evapotranspiration, the guidelines furnished by the FAO 25
Drainage Paper No. 56 (Allen et al., 1998) were referred to and the Hargreaves method (Hargreaves et al., 1985) was used as, near to the study area, only rainfall and temperature data were available. Previously, the Hargreaves method results had been
HESSD

10, 2287-2322, 2013
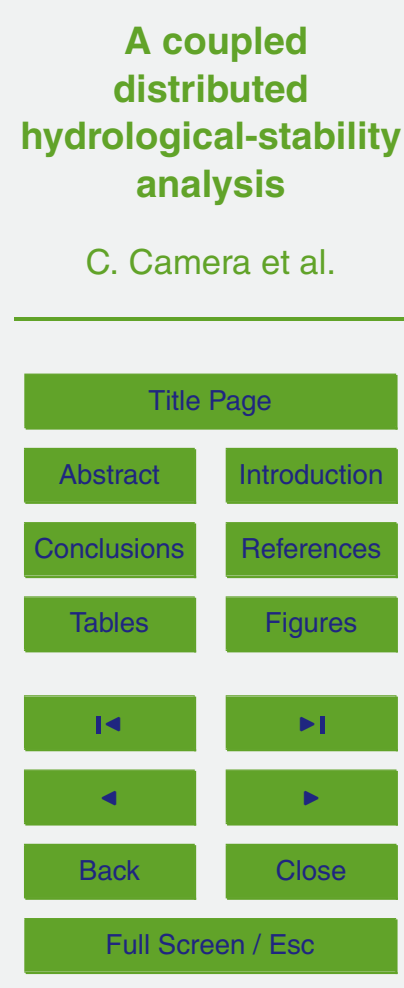

Printer-friendly Version

Interactive Discussion 
calibrated using the Penman-Monteith method (Penman, 1948; Monteith, 1985) at a meteorological station $20 \mathrm{~km}$ away from the study area. In order to obtain the actual evapotranspiration data, the crop factor coefficients were used. Interception was not considered in this study due to the laborious efforts required compared to the benefits 5 that can be gained.

Another difference compared to the original model is that in our study the soil column is considered homogeneous, while van Beek (2002) recognized three different layers with properties changing with depth. This choice was driven by direct observation on site and by the fact that the soil is often rather shallow and its properties are not therefore expected to change drastically.

Once completely parameterized, the model was run with both a daily and an hourly timestep. With the daily timestep the model can reproduce well the general trend of PGTs, whereas with the hourly timestep it tends to underestimate the maximum level but can adequately reproduce the time of the peak, and the slope of the descendant 15 limb of the measured hydrograph (Fig. 5a, b).

The effects of a differently maintained wall were also analyzed along a terrace section. In addition to the observation points at two piezometers, other points were chosen along two sample terraces (Fig. 1) to evaluate the evolution of the water table levels uphill of a single terrace. The differences in the infiltration and groundwater movement processes, due to the different state of wall maintenance, can be better analyzed by looking at the water level and volumetric water content (VWC) values computed by the model along the two sample terraces (Figs. 6 and 7).

With well-maintained walls, both the terraces show a similar trend for VWC (Figs. 6b and $7 \mathrm{~b}$ ). VWC reacts immediately to rainfall, as expected, and variations are strictly correlated to the soil depth of each cell. In general, a high VWC corresponds to a low soil depth. In fact, on sampling terrace 1 the highest VWC is seen in cell 5 where the soil depth is only $0.3 \mathrm{~m}$, and on sampling terrace 2 in cell 6 , which has a soil depth of only $0.4 \mathrm{~m}$. Where the soil is deeper, water takes more time to arrive at the contact point between soil and bedrock and the groundwater table peak is reached after a longer time
HESSD

10, 2287-2322, 2013
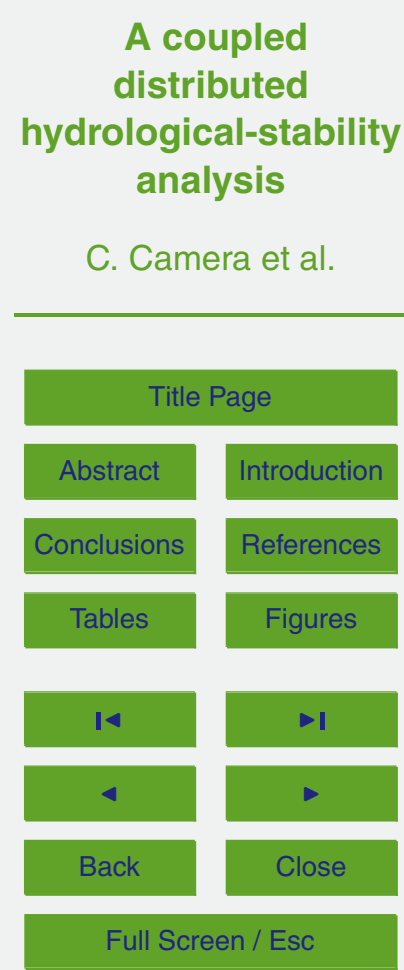

Printer-friendly Version

Interactive Discussion 
period. In addition, it is possible to see how a well-maintained wall is able to drain water and the corresponding cell never reaches a saturated level. Changing the conditions of the wall to a poorly maintained status (Figs. 6d and 7d) shows that all the cells, except those of walls and cell 7 on terrace 1, maintain the same evolution of VWC. The VWC 5 calculated for cells with poorly-maintained walls is always lower than that calculated for cells with well-maintained walls, and a less segmented general trend of VWC can be observed. A lower infiltration capacity can in fact cause a lower effective infiltration into the cell and a lower $k_{\mathrm{s}}$ can reduce the velocity of water redistribution in both vertical and lateral directions. The effect is that within the cell there is less water, but because 10 it is moving slower it can remain there for a longer time. This behavior reflects not only upon VWC but also on the evolution of the water table levels (Figs. 6e and 7e).

The VWC trend of cell 7 on sampling terrace 1 is related to the reduced soil depth of the cell $(0.45 \mathrm{~m})$ and to the water filtration from the uphill cell, which comprises only a wall. The wall has a low hydraulic conductivity and so it slowly releases water in the 15 form of saturated flux to cell 7 . Although cell 7 has no water in its unsaturated level, its water table level lasts for several timesteps, fed by the uphill cell. The following, up and down, trend of cell 7 for both VWC and water table levels depends on the cell reaching saturation point (Fig. $6 \mathrm{~d}, \mathrm{e}$ ). In fact, if saturated, the cell cannot receive further input of water, but can only lose it by saturated flux and evapotranspiration. The model does not allow internal loops and a recharge during the timestep so, in order to avoid a complete drying of the cell in the step following saturation, the model ascribes a VWC to the cell that corresponds to the field capacity. The excess of water in respect of this VWC remains available for drainage. Therefore, the water table can disappear during the step following saturation, but the VWC cannot be lower than the field capacity.

25 A similar situation can be observed not only for cell 7 on sampling terrace 1 but also for the wall cell 1 on sampling terrace 2 . This wall cell shows water levels higher than the wall of sampling terrace 1 , which are probably related to higher contributions from surroundings cells.

\section{HESSD}

10, 2287-2322, 2013

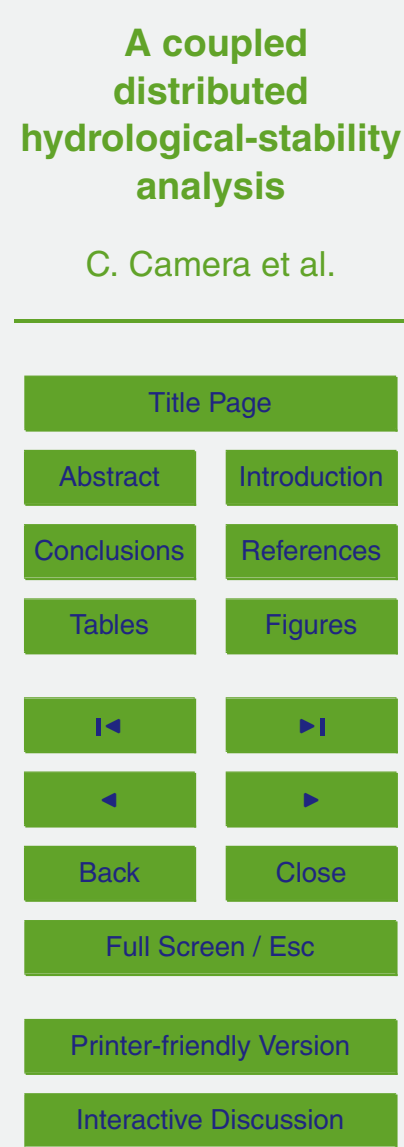

A coupled

-
$\frac{\nabla}{\infty}$
$\frac{0}{\infty}$
$\frac{c}{\infty}$
$\frac{0}{0}$
$\frac{0}{0}$

.


Additional data to be verified includes the water budget check. At the end of the month, the total water input to the area is equal to $103647 \mathrm{~m}^{3}$, while total output is $65629 \mathrm{~m}^{3}$, with a total storage of $37752 \mathrm{~m}^{3}$. The difference between input and the sum of output and total storage is equal to $+266 \mathrm{~m}^{3}$, that is an error of $0.25 \%$ indicating the 5 respect of groundwater mass balance.

For the stability model, the physical and mechanical parameters of walls and soil were defined using the values obtained during the laboratory tests or from the results of the detailed scale stability model (Camera et al., 2012b) summarized in Table 1. The input water level and volumetric water content are the results obtained through 10 the STARWARS modeling. An example of outputs from STARWARS and SARGLE is presented in Fig. 8.

Although the stability model is still under development, interesting results have already emerged. At the present stage of the research, the stability model shows a general tendency to overestimate the amount of unstable areas and an investigation of the causes of this unexpected behavior was therefore performed to progressively improve its reliability. Only results concerning the month of September 2010 are presented, and in particular only those calculated with draining walls and a daily timestep. Results from one dry day and the wettest day of September 2010 (1st and 19th) were used to thoroughly investigate how the model works and to better understand its actual deficiencies.

In general, among the 16441 sections analyzed, 15755 are stable in both dry and wet conditions (SS), 651 are always unstable (UU), 24 are stable in dry conditions and unstable on the 19th of September (SU), while 11 sections are unstable in dry conditions and stable when water is present in the ground (US). First of all, attention was turned to understanding the differences between the SS-terraces and the UU-terraces. The UU-terraces are also unstable in dry conditions; the causes of this instability and the differences compared to the SS-terraces were therefore looked for among their geometrical characteristics. In particular, the height of the wall (Fig. 9), the slope of the

\section{HESSD}

$10,2287-2322,2013$
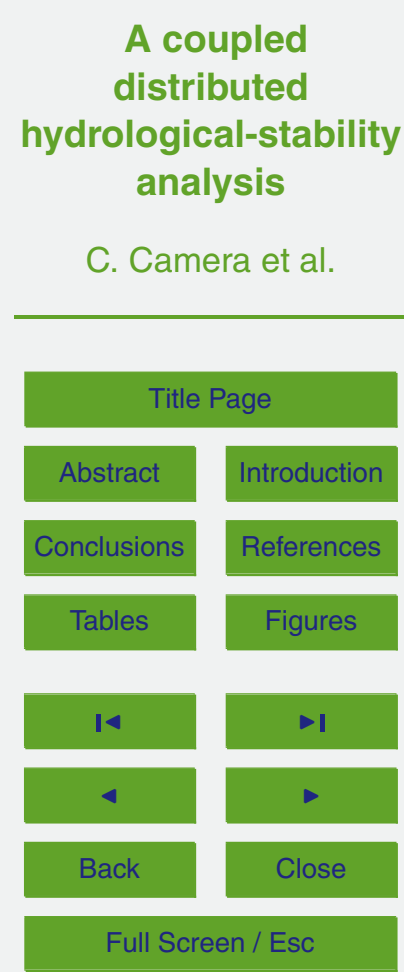

Printer-friendly Version

Interactive Discussion 
bedrock and the soil depth (Fig. 10), and the length (uphill-downhill) of the terraces were analyzed.

The detailed analysis of all unstable cells shows that there is a general increment of the percentage of UU-terraces as the wall height increases (Fig. 9a). The relative 5 probability of failure is more evident for walls higher than $2 \mathrm{~m}$ (Fig. 9b) and a terrace length of more than $20 \mathrm{~m}$.

A key role is also played by the slope of the bedrock (Fig. 10a). In fact both the maximum and mean bedrock surface slope of the UU-terraces are clearly higher compared to the ones of the SS-terraces. Bedrock slope therefore can be assessed as one 10 of the most evident factor predisposing to instability. It must be added that the value used in the calculation of bedrock surface slope is along its north-south component, calculated using the aspect map of the bedrock surface itself. This was driven by the fact that the terrace sections of the calculation are aligned in this direction. Using this apparent slope, all the bedrock surface cells facing north, north-east, and north-west showed a negative slope value which caused problems when running the model. As a first approximation, all these values were arbitrarily set equal to 0 . This decision is safety oriented but it represents a cause of the overestimation of unstable terraces and therefore needs to be examined in depth in the further development of the model.

In addition, the percentage of UU tends to increase with the maximum soil depth 20 (Fig. 10b). Conversely, no great differences between SS and UU-terraces were determined in relation to minimum and mean soil depth except that it was noticed that when along a terrace line the minimum soil depth is zero (local bedrock outcrop) often the terrace is a UU-terrace. Rock outcrops break the continuity of the soil and also of the interslice forces, thus causing a miscalculation. The exclusion of bedrock outcrop cells from the analysis will therefore be one of the first improvements that will be added to the model in the near future.

In respect of the SU-terraces, the expectation is to observe geometrical characteristics that have values between those of SS and UU-terraces and/or that are quite similar to those of UU-terraces. The idea is that these SU-terraces have geometrical
HESSD

10, 2287-2322, 2013

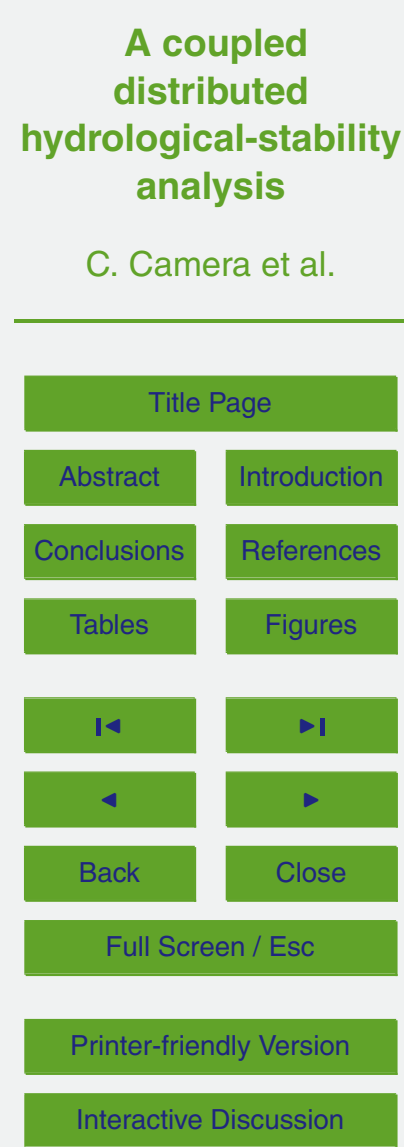

A coupled

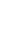

西

西

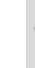

-

\section{(1)}


characteristics quite close to those causing failure, but they also need the contribution of a developing water pressure in order to decrease the resistant forces before collapsing.

This idea is confirmed by an in-depth view of the geometrical properties of these 5 US-terraces where it is possible to observe that the distributions of the wall heights (Fig. 9b), maximum bedrock surface slope (Fig. 10a), and maximum soil depth (Fig. 10b) are not so different from those of the UU terraces and are sometimes between those of SS-terraces and UU-terraces. These geometrical and geological features seem to have the major control on the formation of PGT. During the wet timestep

10 it is evident that the SU-terraces tend to have a higher mean water level, thus showing the effects of a well developed PGT.

It remains to be explained why 11 terraces are unstable in dry conditions and stable in wet conditions. For these US-terraces, it can be seen that $80 \%$ ( 9 out of 11 ) have at least one cell with a soil depth of zero. In this case, it could be a miscalculation due 15 to the broken continuity of inter-slice forces. However, for the remaining 2 terraces, the observed results cannot be explained so easily. They could be due to a combination of factors, or to the inability of the method to adequately solve stability equations when saturated levels are very low and discontinuous along the terrace; this point is still under investigation.

\section{Conclusions}

Reproducing the dynamics of water table formation within an extended study area is important in order to recognize areas that are more prone to water accumulation and so are more critical from a stability point of view. In particular, the hydrogelogical model is required to reproduce the maximum water levels registered on site, because they correspond to the most critical situations. STARWARS was therefore tested, and its results compared, at different temporal scales. In particular, daily and hourly timesteps were used. With the daily resolution, the model is able to reproduce well the water table

\section{HESSD}

10, 2287-2322, 2013

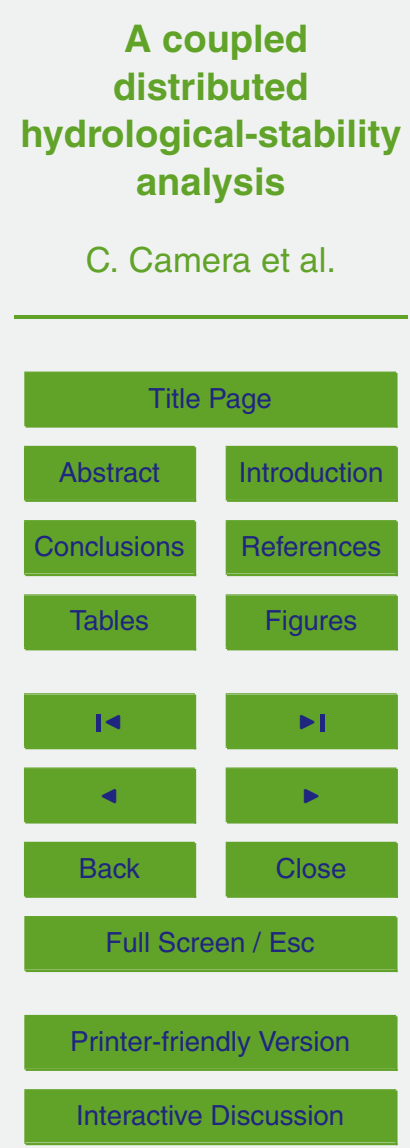

A coupled

gical-stal

analysis

C. Camera et al. 
peaks, though with a single timestep delay. With the hourly timestep, the time of the peak is satisfactorily reproduced but the model tends to underestimate the maximum height reached by the water table. Also the difference in the behavior between a draining and a non-draining wall is often limited to the cell that corresponds to the dry-stone 5 wall itself. Despite this, it is possible to confirm that the model can adequately perform the expected task, in fact it is able to produce reliable series of water levels and water content maps to use as input in the stability model.

More problems arose during the stability analysis. The particular morphology of the study area and the need to include dry-stone walls in the analysis required the use of 10 high resolution base maps for raster analysis. The use of these maps excluded the possibility of using a simple infinite-slope model. The calculation was performed cell by cell and the soil depth of a $1 \mathrm{~m} \times 1 \mathrm{~m}$ cell was never negligible compared to its length. It was therefore decided to try to implement a model based on the slices equilibrium method for both circular and non-circular failure surfaces (Sarma, 1973). The method does not consider the equilibrium of the single cell (slice) but of a group of cells (slices) along the same failure surface. In this analysis, many failure surfaces were considered, one for every recognized terrace line, which is formed by the single alignments of the cells comprised between two successive walls including the cell representing the downslope wall. The failure surfaces are assumed coincident with the contact point between soil and bedrock. Considering these few pieces of information, it is possible to understand how the model results depend on soil depth and bedrock geometry. Great efforts were in fact made during this research to obtain a good soil depth map and a reliable digital elevation model at the required resolution, from which it was later possible to calculate the differing geometries of the bedrock. Despite these efforts, the first preliminary results of the model were not very satisfactory. By modifying the slope map in order to avoid negative slopes, a limited but meaningful number of terrace lines were shown as unstable, even under completely dry soil conditions. The causes of this result needed to be considered in two different ways. One possibility is that along certain slip surfaces the failure is not admissible from a kinematics point of view. Another possibility is that

\section{HESSD}

10, 2287-2322, 2013
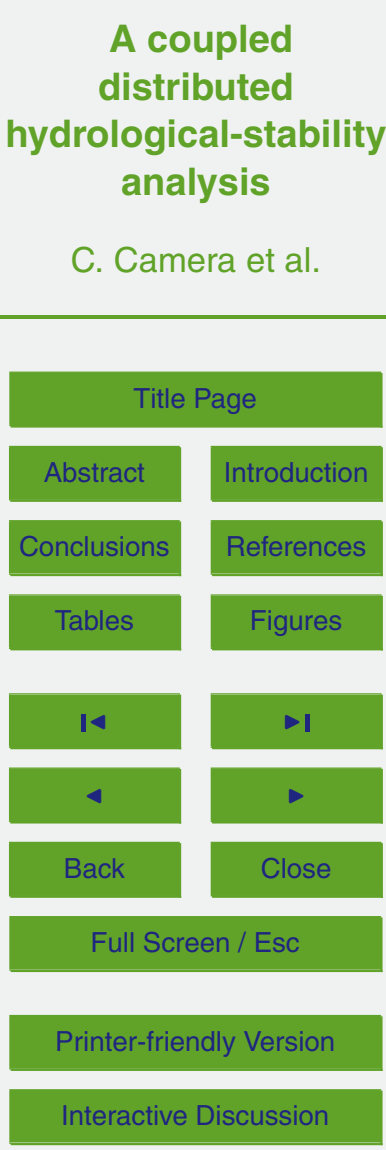
the Digital Elevation Model (DEM) and the soil depth map could have been estimated incorrectly, thus causing certain slopes to falsely show instability. Both these factors were, in part, confirmed by the analysis carried out comparing the results obtained in both dry and wet conditions. In one case, the distribution of the bedrock surface slope 5 in the terraces that were unstable even in dry conditions suggests a problem in the determination of topography and the soil depth map. In respect of the kinematics admissibility of the failures observed, it could be that cells with a zero soil depth still present inside the different terrace lines can cause problems in the calculation of the interslices forces. However, the modification that ensured a minimum bedrock surface slope of $0^{\circ}$ 10 along the direction of the analysis may also have created false results. Besides these limitations, that have been acknowledged and will be further investigated and fixed, the model showed a very good sensitivity to increasing water levels, thus giving confidence for its reliable use after the necessary modifications have been implemented.

\section{References}

15 Akbas, S. O., Blahut, J., and Sterlacchini, S.: Critical assessment of existing physical vulnerability estimation approaches for debris flows, in: Proceedings of Landslide Processes: From Geomorphologic Mapping to Dynamic Modelling, edited by: Malet, J. P., Remaitre, A., and Bogaard, T., Strasburg, France, 6-7 February 2009, 229-233, 2009.

Allen, R. G., Pereira, L. S., Raes, D., and Smith, M.: Irrigation and Drainage Paper No. 56, FAO, Rome, 326 pp., 1996.

Angeli, M. G., Buma, J., Gasparetto, P., and Pasuto, A.:. A combined hillslope hydrology/stability model for low-gradient clay scope in the Italian Dolomites, Eng. Geol. 49, 1-13. doi:10.1016/S0013-7952(97)00033-1, 1998.

Azzola, M. and Tuia, T.: Osservazione sui fenomeni franosi che hanno interessato i vigneti terrazzati a monte di Tresenda nel maggio 1983, Geologia Tecnica 4, 23-35, 1983.

Baum, R. L., Savage, W. Z., and Godt, J. W.: TRIGRS - A Fortran Program for Transient Rainfall Infiltration and Grid Based Regional Slope Stability Analysis, Open file report 02-424, US Department of the Interior and US Geological Survey, Denver, CO, 2002.

\section{HESSD}

10, 2287-2322, 2013

\section{A coupled \\ distributed \\ hydrological-stability \\ analysis \\ C. Camera et al.}

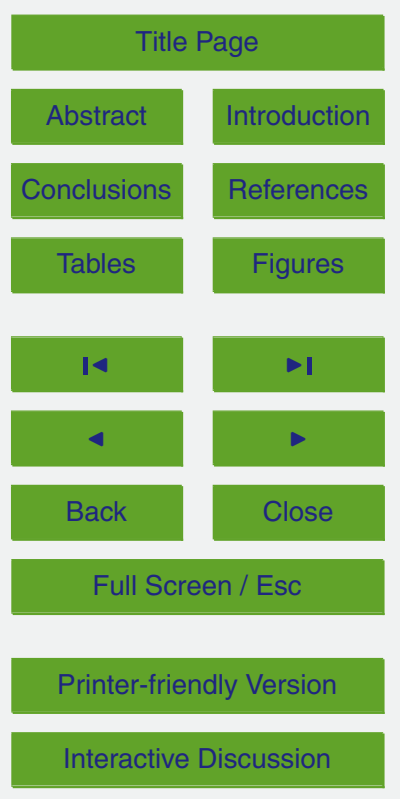


Biavati, G., Godt, J. W., and McKenna, J. P.: Drainage effects on the transient, near-surface hydrologic response of a steep hillslope to rainfall: implications for slope stability, Edmonds, Washington, USA, Nat. Hazards Earth Syst. Sci., 6, 343-355, doi:10.5194/nhess-6-3432006, 2006.

5 Blahut, J., van Westen, C., and Sterlacchini, S.:. Analysis of landslide inventories for accurate prediction of debris-flow source areas, Geomorphology, 119, 36-51, doi:10.1016/j.geomorph.2010.02.017, 2010a.

Blahut, J., Horton, P., Sterlacchini, S., and Jaboyedoff, M.: Debris flow hazard modelling on medium scale: Valtellina di Tirano, Italy, Nat. Hazards Earth Syst. Sci., 10, 2379-2390, doi:10.5194/nhess-10-2379-2010, 2010b.

Blahut, J., Poretti, I., De Amicis, M., and Sterlacchini, S.: Database of geo-hydrological disasters for civil protection purposes, Nat. Hazards 60, 1065-1083, doi:10.1007/s11069-011-9893-6, 2012.

Camera, C., Masetti, M., and Apuani, T.: Rainfall, infiltration, and groundwater flow in a terraced slope of Valtellina (northern Italy): field data and modelling, Environ. Earth Sci., 65, 11911202, doi:10.1007/s12665-011-1367-3, 2012a.

Camera, C., Apuani, T., and Masetti, M.: Mechanisms of failure on terraced slopes: the Valtellina case (northern Italy), Landslides, doi:10.1007/s10346-012-0371-3, online first, 2012b.

Cancelli, A. and Nova, R.: Landslides in soil debris cover triggered by rainstorms in Valtellina (Central Alps - Italy), in: Proc. IV International Conference and Field Workshop on Landslides, Tokio, 267-272, 23-31 August, 1985.

Cho, S. E.: Infiltration analysis to evaluate the surficial stability of two-layered slopes considering rainfall characteristic, Eng. Geol. 105, 32-43, doi:10.1016/j.enggeo.2008.12.007, 2009.

Crosta, G. B. and Frattini, P.: Distributed modelling of shallow landslides triggered by intense rainfall, Nat. Hazards Earth Syst. Sci., 3, 81-93, doi:10.5194/nhess-3-81-2003, 2003.

Crosta, G. B., Dal Negro, P., and Frattini, P.: Soil slips and debris flows on terraced slopes, Nat. Hazards Earth Syst. Sci., 3, 31-42, doi:10.5194/nhess-3-31-2003, 2003.

DB2000: Database of the CM Valtellina di Tirano mapped at $1: 2000$ scale, CM Valtellina di Tirano, CD-ROM, available at: http://www.cmtirano.so.it/sistemainformativo.php, 2003.

so Delmonaco, G., Leoni, G., Margottini, C., Puglisi, C., and Spizzichino, D.: Large scale debrisflow hazard assessment: a geotechnical approach and GIS modelling, Nat. Hazards Earth Syst. Sci., 3, 443-455, doi:10.5194/nhess-3-443-2003, 2003.
HESSD

$10,2287-2322,2013$

A coupled

distributed

hydrological-stability

analysis

C. Camera et al

Title Page

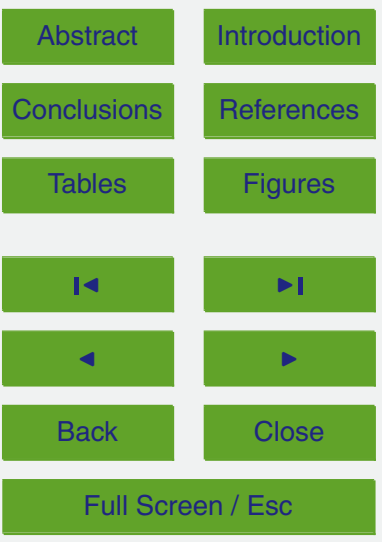

Printer-friendly Version

Interactive Discussion 
Dietrich, W. E. and Montgomery, D. R.: SHALSTAB: A Digital Terrain Model for Mapping Shallow Landslide Potential, University of California and University of Washington, Berkeley, CA, 1998.

EM-DAT: The OFDA/CRED International Disaster Database, www.emdat.be (last access: September 2012), 2010.

Ewen, J., Parkin, G., and O'Connell, P. E.: SHETRAN: distributed river basin flow and transport modeling system, J. Hydrol. Eng., 5, 250-258, 2000.

Farrel, D. and Larson, W.: Modelling the pore structure of porous media, Water Resour. Res., 8, 699-705, 1972.

10 Gessler, P., Moore, I., McKenzie, N., and Ryan, P.: Soil-landscape modelling and spatial prediction of soil attributes, Int. J. Geogr. Inf. Syst., 9, 421-432, 1995.

Goovaerts, P.: Using elevation to aid the geostatistical mapping of rainfall erosivity, Catena, 34, 227-242, 1999.

Hargreaves, G. L., Hargreaves, G. H., and Riley, J. P.: Agricultural benefits for Senegal River 15 Basin, J. Irrig. Drain. E.-ASCE, 111, 113-124, 1985.

Krige, D. G.: A Statistical approach to some basic mine valuation problems on the Witwatersrand, Journal of the Chemical, Metallurgical and Mining Society of South Africa, 52, 119139, 1951.

Kuriakose, S. L., van Beek, L. P. H., and van Westen, C. J.: Parameterizing a physically based shallow landslide model in a data poor region, Earth Surf. Proc. Land., 34, 867-881, doi:10.1002/esp.1794, 2009a.

Kuriakose, S. L., Devkota, S., Rossiter, D. G., and Jetten, V. G.: Prediction of soil depth using environmental variables in an anthropogenic landscape, a case study in the Western Ghats of Kerala, India, Catena 79, 27-38, doi:10.1016/j.catena.2009.05.005, 2009b.

Ray, R. L., Jacobs, J. M., and Ballestero, T. P.: Regional landslide susceptibility: spatiotemporal variations under dynamic soil moisture conditions, Nat. Hazards, 59, 1317-1337, doi:10.1007/s11069-011-9834-4, 2011.

Malet, J.-P., van Asch, Th. W. J., van Beek, R., and Maquaire, O.: Forecasting the behaviour of complex landslides with a spatially distributed hydrological model, Nat. Hazards Earth Syst.

$30 \quad$ Sci., 5, 71-85, doi:10.5194/nhess-5-71-2005, 2005.

McBratney, A., Odeh, I., Bishop, T., Dunbar, M., and Shatar, T.: An overview of pedometric techniques of use in soil survey, Geoderma, 97, 293-327, 2000.
HESSD

10, 2287-2322, 2013

A coupled

distributed

hydrological-stability

analysis

C. Camera et al.

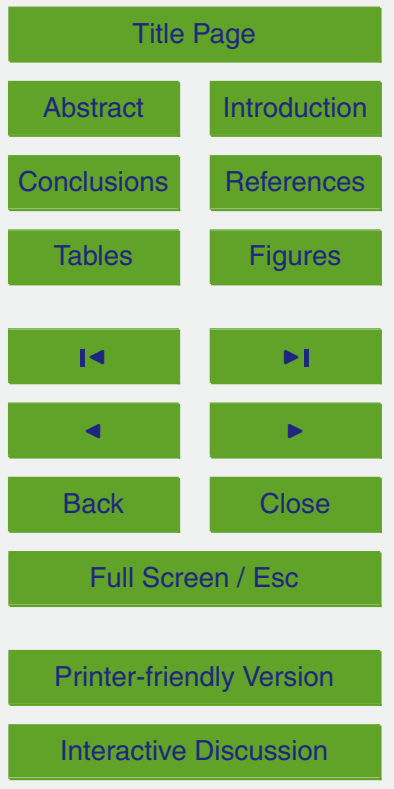


McKenzie, N. and Ryan, P.: Spatial prediction of soil properties using environmental correlation, Geoderma, 89, 67-94, 1999.

Meisina, C. and Scarabelli, S.: A comparative analysis of terrain stability models for predicting shallow landslides in colluvial soils, Geomorphology, 87, 207-223, 5 doi:10.1016/j.geomorph.2006.03.039, 2007.

Millington, R. J. and Quirk, J. P.: Permeability of porous media, Nature, 183, 387-388, 1959.

Millington R. J. and Quirk, J. P.: Permeability of porous media, T. Faraday Soc., 57, 1200-1207, 1961.

Monteith, J. L.: Evaporation from land surfaces: progress in analysis and prediction since 1948, in: in Advances in Evapotranspiration, Proceedings of the ASAE Conference on Evapotranspiration, Chicago, III. ASAE, St. Joseph, Michigan, 25-28 February, 4-12, 1985.

Montrasio, L., Valentino, R., and Losi, G. L.: Shallow landslides triggered by rainfalls: modeling of some case histories in the Reggiano Apennine (Emilia Romagna Region, northern Italy), Nat. Hazards, 60, 1231-1254, doi:10.1007/s11069-011-9906-5, 2012.

Moore, I., Gessler, P., Nielsen, G., and Peterson, G.: Soil attribute prediction using terrain analysis, Soil Sci. Soc. Am. J., 57, 443-452, 1993.

Odeh, I., McBratney, A., and Chittleborough, D.: Spatial prediction of soil properties from landform attributes derived from a digital elevation model, Geoderma, 63, 197-214, 1994.

Odeh, I., McBratney, A., and Chittleborough, D.: Further results on prediction of soil properties from terrain attributes: heterotopic cokriging and regression-kriging, Geoderma, 67, 215226, 1995.

Penman, H. L.: Natural evaporation from open water, bare soil and grass, P. Roy. Soc. Lond. A, 193, 120-146, 1948.

Pack, R. T., Tarboton, D. G., and Goodwin, C. N.: The SINMAP Approach to Terrain stability Mapping, in: Proc 8th Congress of the International Association of Engineering Geology, Vancouver, British Columbia, Canada, International Association of engineering, Paris, 2125 September, 1998.

Quan Luna, B., van Westen, C. J., Blahut, J., Camera, C., Apuani, T., and Sterlacchini, S.: From deterministic hazard modelling to risk and loss estimation. In: Mountain Risks: Bringing 30 Science to Society, in: Proceedings of the International Conference, 24-26 November 2010, Florence, Italy, CERG Editions, Strasbourg, France, 373-380, 2010.

\section{A coupled \\ distributed \\ hydrological-stability \\ analysis \\ C. Camera et al.}

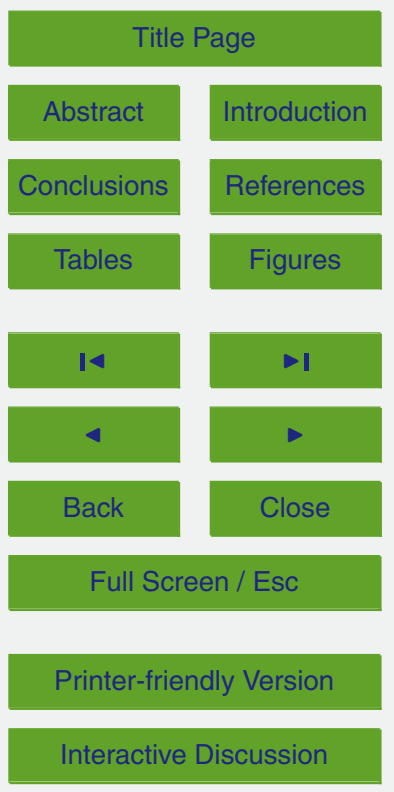


Quan Luna, B., Blahut, J., Camera, C., van Westen, C. J., Apuani, T., Jetten, V., and Sterlacchini, S.: Quantitative risk assessment for debris flows based on physically-based dynamic run-out modelling, a case study in Tresenda, northern Italy, Nat. Hazards, in review, 2013.

Revellino, P., Guadagno, F. M., and Hungr, O.: Morphological methods and dynamic modeling 5 in landslide hazard assessment of the Campania Apennine carbonate slope, Landslides, 5, 59-70, doi:10.1007/s10346-007-0103-2, 2008.

Richards, L. A.: Capillary conduction of liquids through porous mediums, Physics, 1, 318-333, 1931.

Samui, P. and Sitharam, T. G.: Machine learning modelling for predicting soil liquefaction susceptibility, Nat. Hazards Earth Syst. Sci., 11, 1-9, doi:10.5194/nhess-11-1-2011, 2011.

Sarma, S. K.: Stability analysis of embankments and slopes, Geotechnique, 23, 423-433, 1973.

Sarma, S. K.: Stability analysis of embankments and slopes, J. Geotech. Eng.-ASCE, 12, 1511-1524, 1979.

Sarma, S. K. and Bhave, M. V.: Critical acceleration versus static factor of safety in stability analysis of earth dams and embankments, Geotechnique, 24, 661-665, 1974.

Schmidt, J., Turek, G., Clark, M. P., Uddstrom, M., and Dymond, J. R.: Probabilistic forecasting of shallow, rainfall-triggered landslides using real-time numerical weather predictions, Nat. Hazards Earth Syst. Sci., 8, 349-357, doi:10.5194/nhess-8-349-2008, 2008.

20

Segoni, S., Rossi, G., and Catani, F.: Improving basin scale shallow landslide modelling using reliable soil thickness maps, Nat. Hazards, 61, 85-101, doi:10.1007/s11069-011-9770-3, 2012.

Simoni, S., Zanotti, F., Bertoldi, G., and Rigon, R.: Modelling the probability of occurance of shallow landslides and channelized debris flows using GEOtop-SF, Hydrol. Process., 22, 532-545, 2008.

Sterlacchini, S., Ballabio, C., Blahut, J., Masetti, M., and Sorichetta, A.: Spatial agreement of predicted patterns in landslide susceptibility maps, Geomorphology, 125, 51-61, doi:10.1016/j.geomorph.2010.09.004, 2011.

Talebi, A., Troch, P. A., and Uijlenhoet, R.: A steady-state analytical slope stability model for complex hillslopes, Hydrol. Process., 22, 546-553, doi:10.1002/hyp.6881, 2008.

Tofani, V., Dapporto, S., Vannocci, P., and Casagli, N.: Infiltration, seepage and slope instability mechanisms during the 20-21 November 2000 rainstorm in Tuscany, central Italy, Nat. Hazards Earth Syst. Sci., 6, 1025-1033, doi:10.5194/nhess-6-1025-2006, 2006.
HESSD

10, 2287-2322, 2013

A coupled

distributed

hydrological-stability

analysis

C. Camera et al.

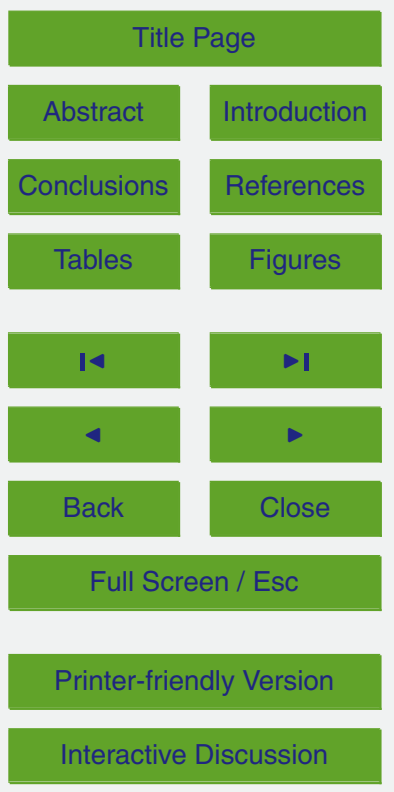


van Beek, L. P. H.: Assessment of the influence of changes in land use and climate on landslide activity in a Mediterranean environment, PhD Thesis, University of Utrecht, Utrecht, The Netherlands, 363 pp., 2002.

van Beek, L. P. H. and van Asch, Th. W. J.: Regional Assessment of the effects of land-use change on landslide hazard by means of physically based modelling, Nat. Hazards, 31, 289304, doi:10.1023/B:NHAZ.0000020267.39691.39, 2004.

\section{HESSD}

10, 2287-2322, 2013

\section{A coupled \\ distributed \\ hydrological-stability \\ analysis \\ C. Camera et al.}

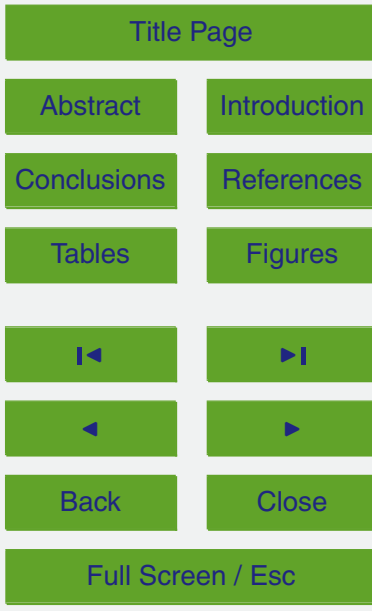

Printer-friendly Version

Interactive Discussion 


\section{HESSD}

10, 2287-2322, 2013

\section{A coupled distributed}

hydrological-stability analysis

Table 1. Hydrogeological and mechanical properties of the materials involved: $\gamma_{d}$ is the dry bulk density $\left[\mathrm{kN} \mathrm{m}^{-3}\right] ; n$ is the porosity $[-] ; \theta_{\text {res }}$ is the residual water content $[-] ; k_{\mathrm{s}}$ is the saturated hydraulic conductivity $\left[\mathrm{ms}^{-1}\right] ; c$ is the cohesion [kPa]; and $\varphi$ is the friction angle [deg].

\begin{tabular}{lcccccc}
\hline & $\gamma_{\mathrm{d}}$ & $n$ & $\theta_{\text {res }}$ & $k_{\mathrm{s}}$ & $c$ & $\varphi$ \\
\hline Soil & 16 & 0.50 & 0.010 & $1 \times 10^{-5}$ & 10 & 30 \\
Bedrock & 26 & 0.07 & 0.000 & $1 \times 10^{-8}$ & 350 & 40 \\
Draining wall & 24 & 0.25 & 0.005 & $5 \times 10^{-4}$ & 120 & 55 \\
Non-draining wall & 24 & 0.25 & 0.005 & $1 \times 10^{-6}$ & 120 & 55 \\
\hline
\end{tabular}

C. Camera et al.

Title Page

Abstract Introduction

Conclusions

References

Tables

Figures

14

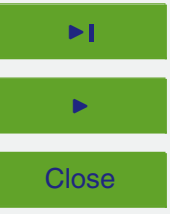

Back

Full Screen / Esc

Printer-friendly Version

Interactive Discussion 


\section{HESSD}

10, 2287-2322, 2013

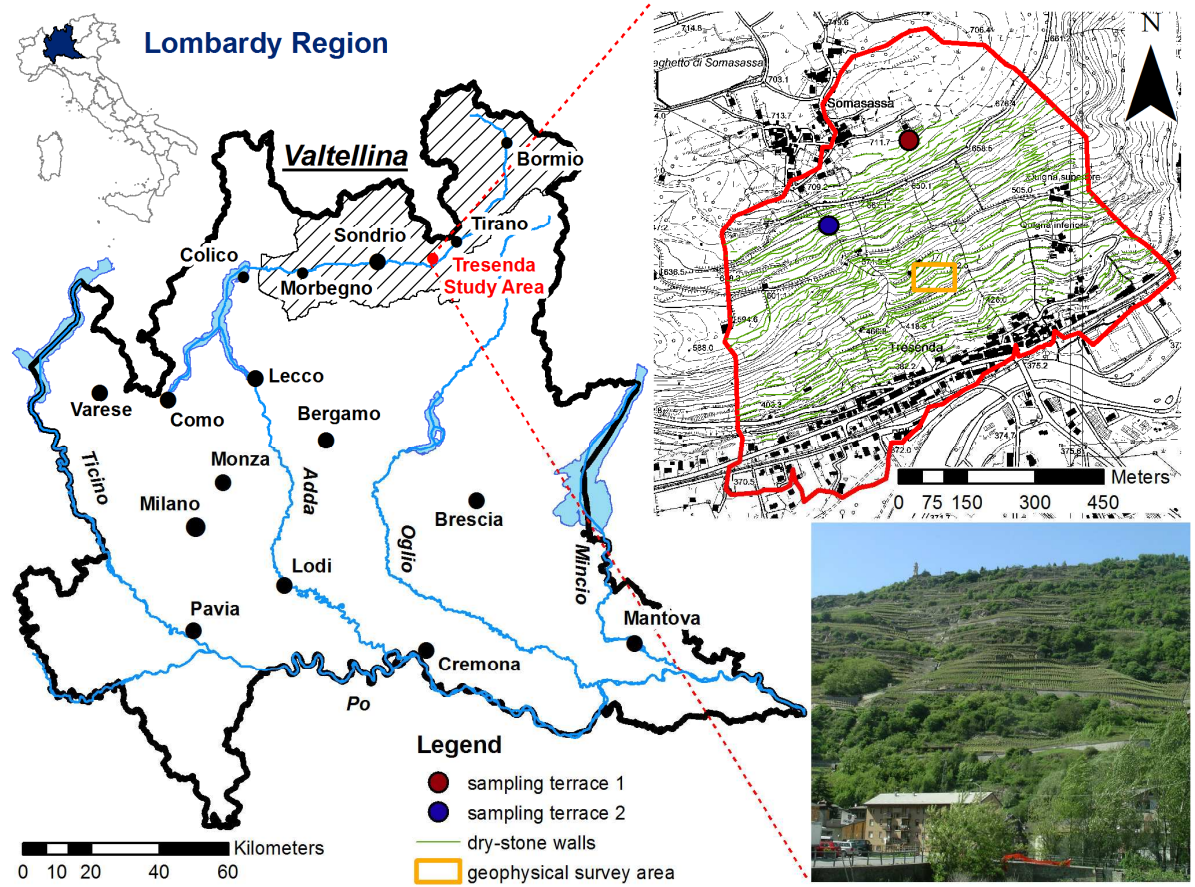

\section{A coupled distributed}

hydrological-stability analysis

C. Camera et al.

\section{Title Page}

14 $\rightarrow$

4

Back

Full Screen / Esc

Printer-friendly Version

Interactive Discussion 


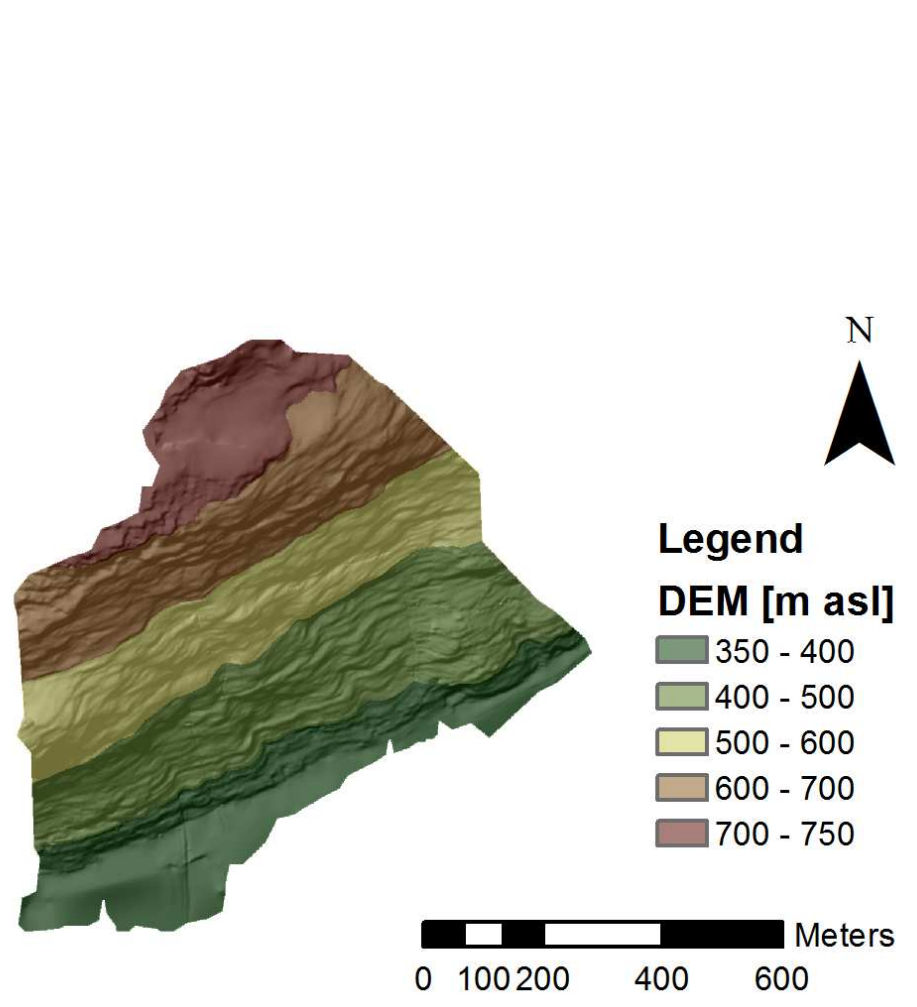

Fig. 2. The digital elevation model with a resolution of $1 \mathrm{~m}$ obtained from photogrammetric analysis.

\section{HESSD}

10, 2287-2322, 2013
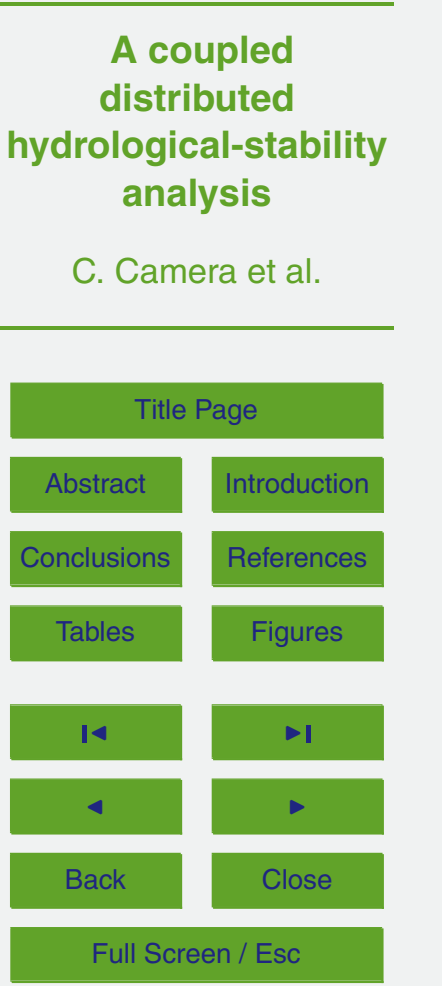

Printer-friendly Version

Interactive Discussion 

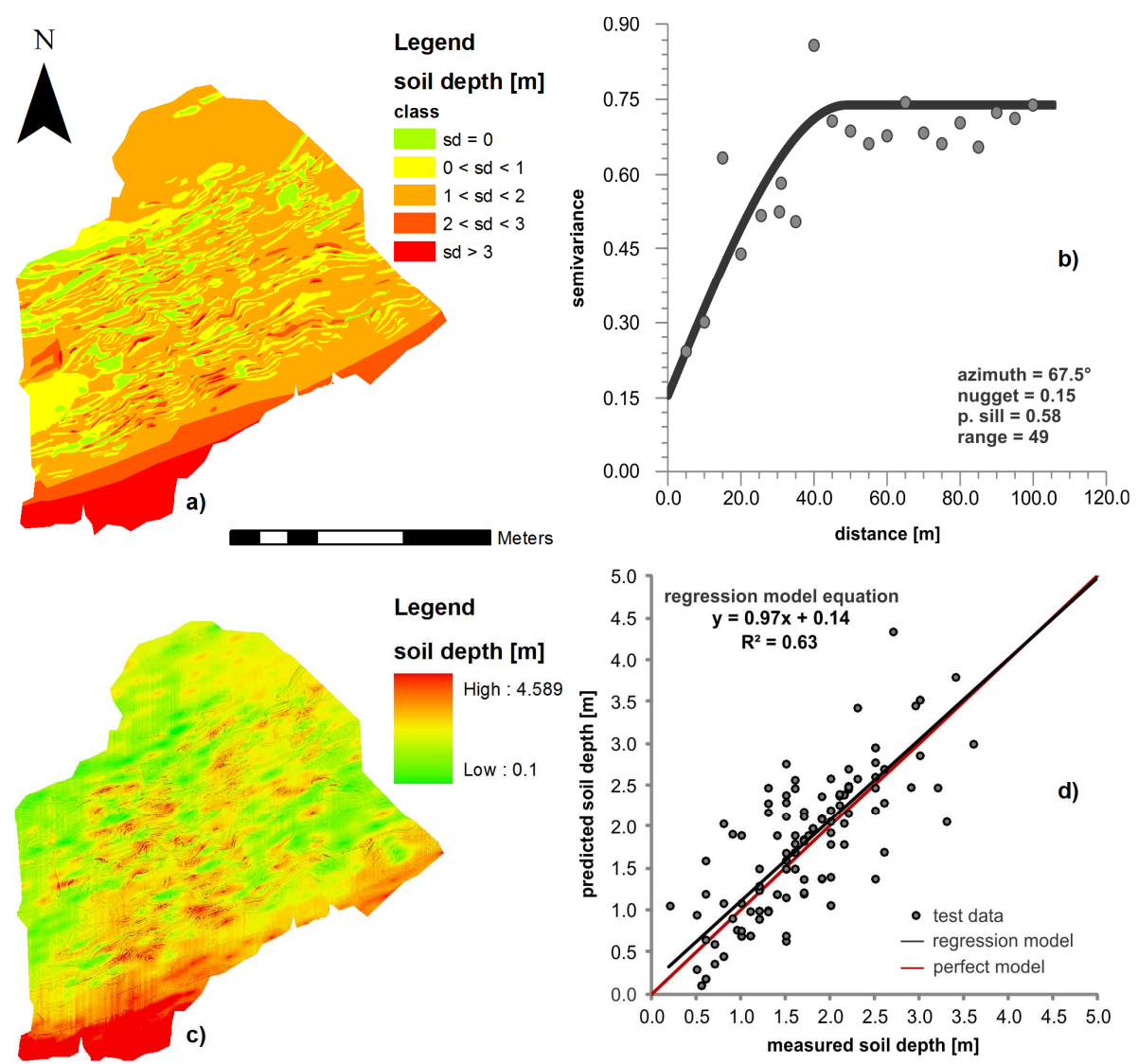

Fig. 3. Top, the soil depth class map (a) and the variogram model obtained from the training points (b) used to perform co-kriging. Bottom, the resulting soil depth map with resolution $1 \mathrm{~m}$ (c) and the validation of the map using test points not previously used in the estimation of the final map.

\section{HESSD}

10, 2287-2322, 2013

\section{A coupled distributed \\ hydrological-stability analysis \\ C. Camera et al.}

\section{Title Page}

Abstract Introduction

Conclusions References

Tables Figures

14 $\rightarrow 1$

$\triangleleft$

Back

Close

\section{Full Screen / Esc}

Printer-friendly Version

Interactive Discussion 


\section{HESSD}

10, 2287-2322, 2013
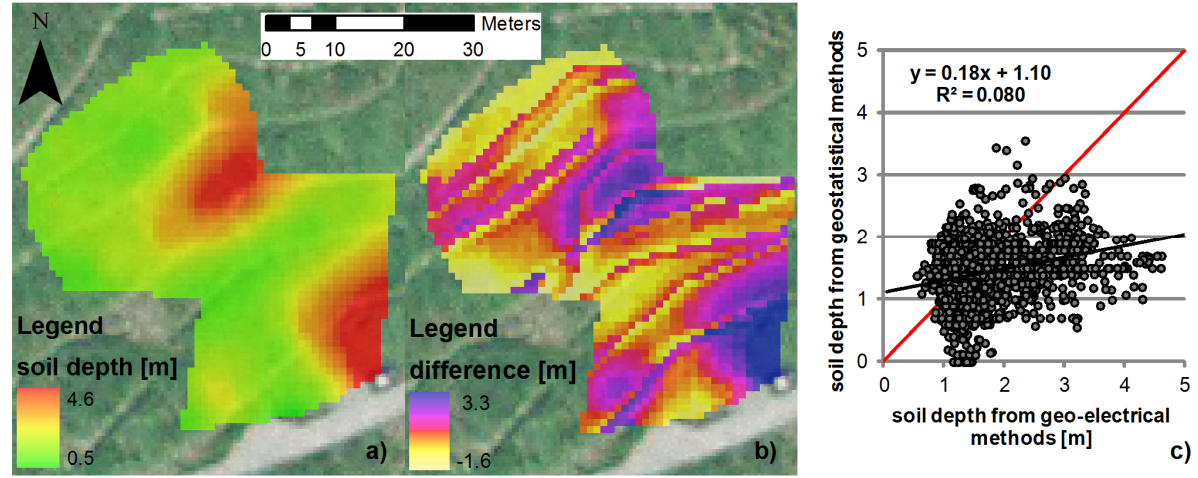

\section{A coupled distributed}

hydrological-stability analysis

C. Camera et al.

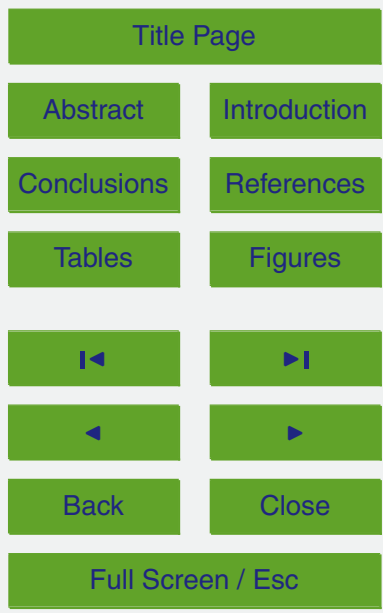

Printer-friendly Version

Fig. 4. The soil depth map with resolution $1 \mathrm{~m}$ obtained on a small area using geophysical indirect methods (a); the differences between the map obtained with geophysical methods and that estimated using the geostatistical analysis (b); the comparison on a simple graph of the two methods (c).

Interactive Discussion 

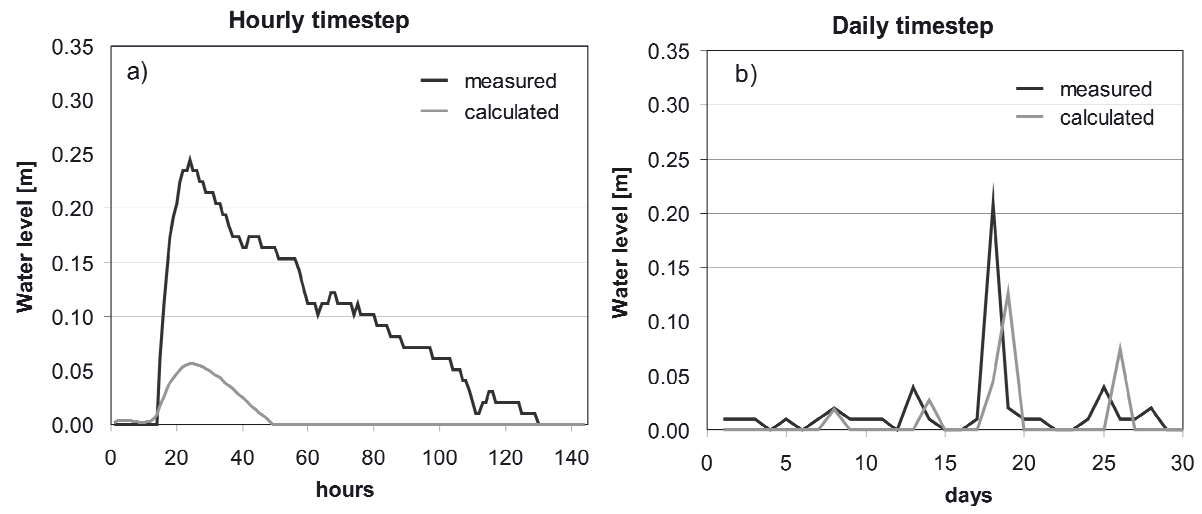

\section{HESSD}

10, 2287-2322, 2013

\section{A coupled distributed}

hydrological-stability analysis

C. Camera et al.

\section{Title Page}

Abstract Introduction

Conclusions

References

Tables

Figures

14

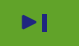

Fig. 5. Hydrographs obtained by the model corresponding to the location of an installed control piezometer, with both an hourly (a) and a daily (b) timestep.

\section{4}

Back

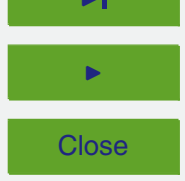

Full Screen / Esc

Printer-friendly Version 

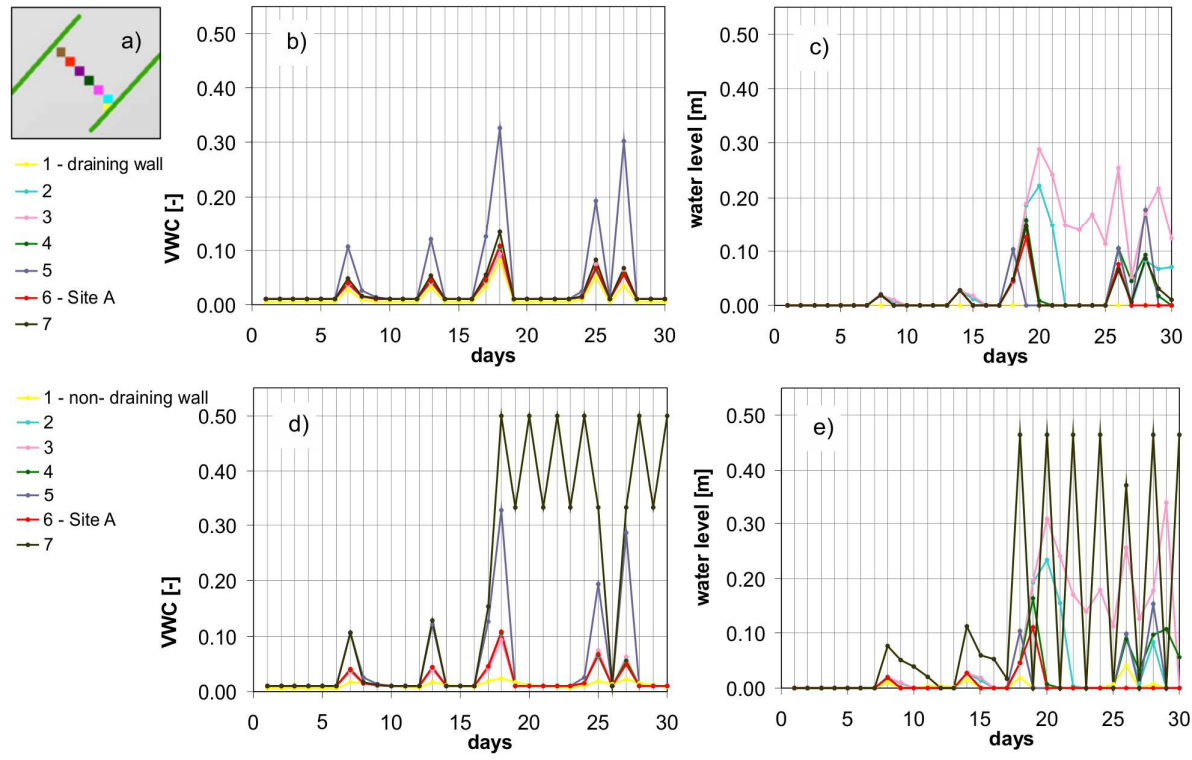

Fig. 6. Results related to sampling terrace 1 (Fig. 1) during the rainfall event of 10 September. Sketch of the cells' alignment (a), cell $n^{\circ} 6$ (Site A) locates the field monitoring station. VWC and water levels obtained with a draining wall $(\mathbf{b}-\mathbf{c})$, and with a non-draining wall (d-e).

\section{A coupled distributed \\ hydrological-stability analysis \\ C. Camera et al.}

\section{Title Page}

Abstract Introduction

Conclusions

References

Tables

Figures

14

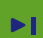

$<$

Back

Close

\section{Full Screen / Esc}

Printer-friendly Version

Interactive Discussion 

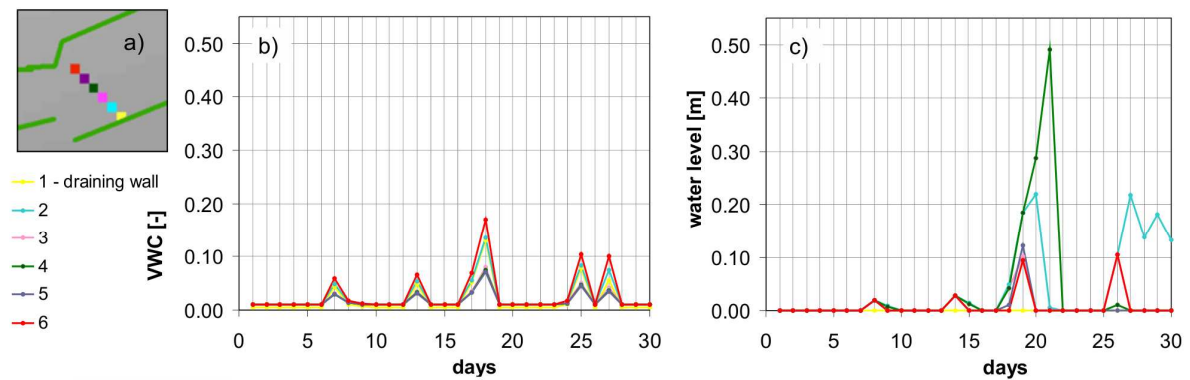

\section{HESSD}

10, 2287-2322, 2013

\section{A coupled distributed \\ hydrological-stability analysis \\ C. Camera et al.}
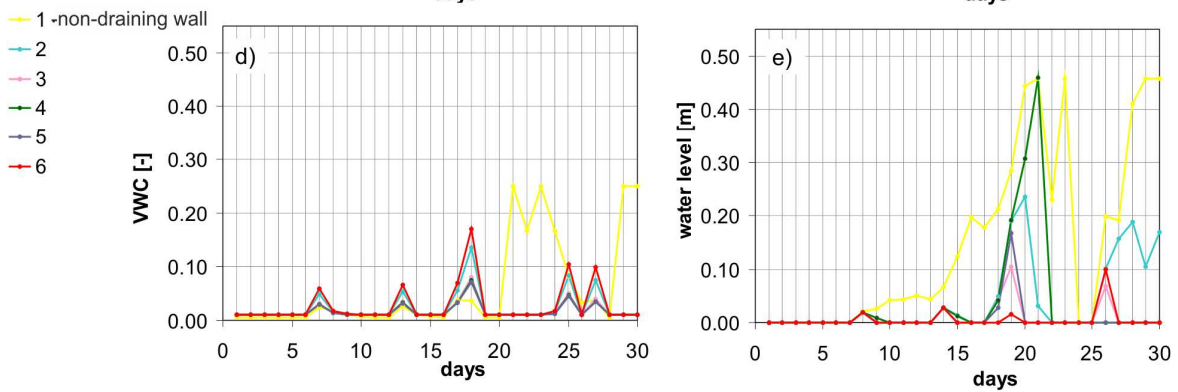

Title Page

Abstract Introduction

Conclusions

References

Tables

Figures

14

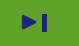

4

Fig. 7. Results related to sampling terrace 2 (Fig. 1) during the rainfall event of 10 September. Sketch of the cells alignment (a). VWC and water levels obtained with a draining wall (b-c), and with a non-draining wall (d-e).

\section{Close}

\section{Full Screen / Esc}

Printer-friendly Version

Interactive Discussion 


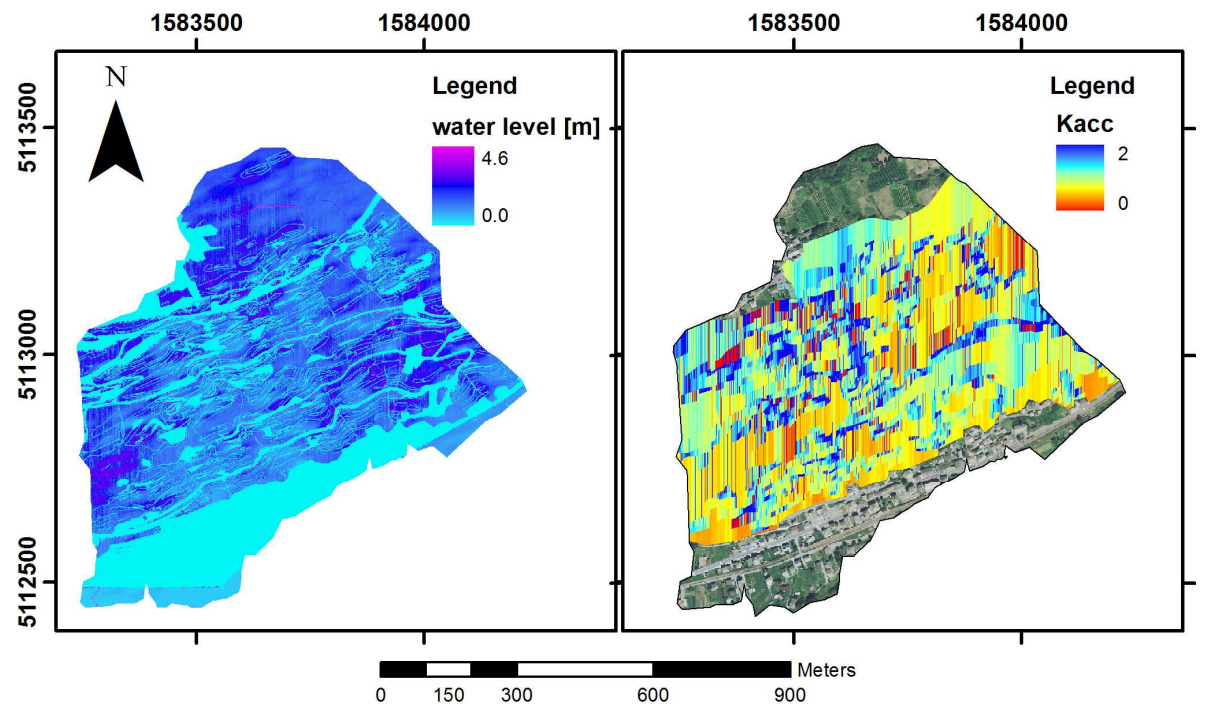

Fig. 8. Left, the water levels along the slope calculated by STARWARS for the 19 September; right, the correspondent critical acceleration $\left(K_{\text {acc }}\right)$ of the different terrace sections calculated by the stability model. The coordinates shown refer to the national projected system of Rome Monte Mario 1.

\section{HESSD}

10, 2287-2322, 2013

\section{A coupled distributed}

hydrological-stability analysis

C. Camera et al.

\section{Title Page}

Abstract Introduction

Conclusions References

Tables

Figures

14

$\rightarrow 1$

4

Back

Close

\section{Full Screen / Esc}

Printer-friendly Version

Interactive Discussion 


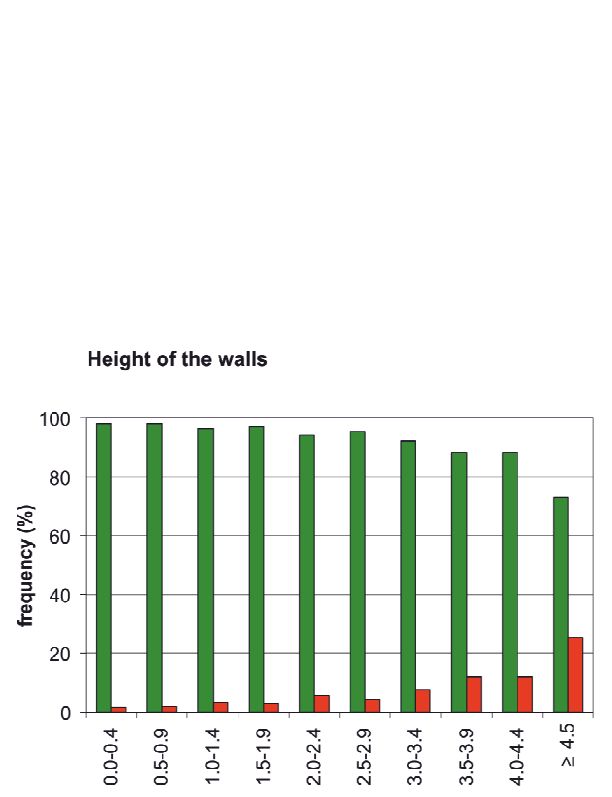

a) height class (m)

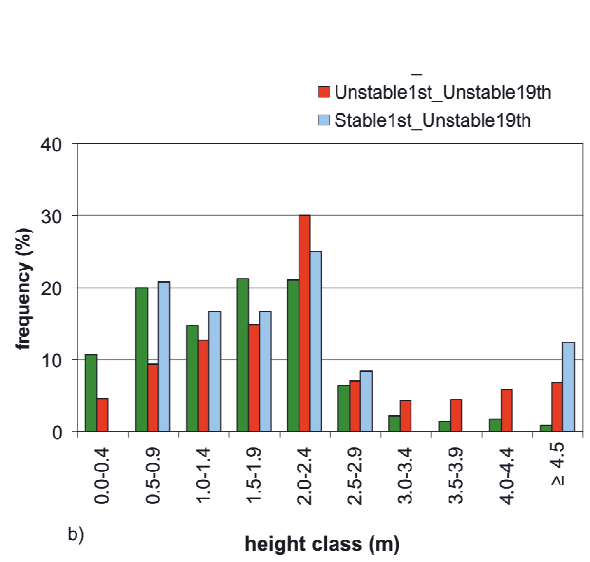

Fig. 9. (a) Frequency diagram of the wall height for both stable (SS) and unstable (UU) terraces. Values are expressed in percentages according to the total number of terraces. (b) Frequency diagram of the wall height for both stable (SS), unstable (UU) and stable-unstable (SU) terraces. Values are expressed in percentages according to the total number of stable (SS), unstable (UU) and stable-unstable (SU) terraces respectively.

\section{HESSD}

10, 2287-2322, 2013

A coupled

distributed

hydrological-stability analysis

C. Camera et al.

\section{Title Page}

Abstract Introduction

Conclusions

References

Tables

Figures

14

$\rightarrow$

$\triangleleft$

Back

Close

\section{Full Screen / Esc}

Printer-friendly Version

Interactive Discussion 

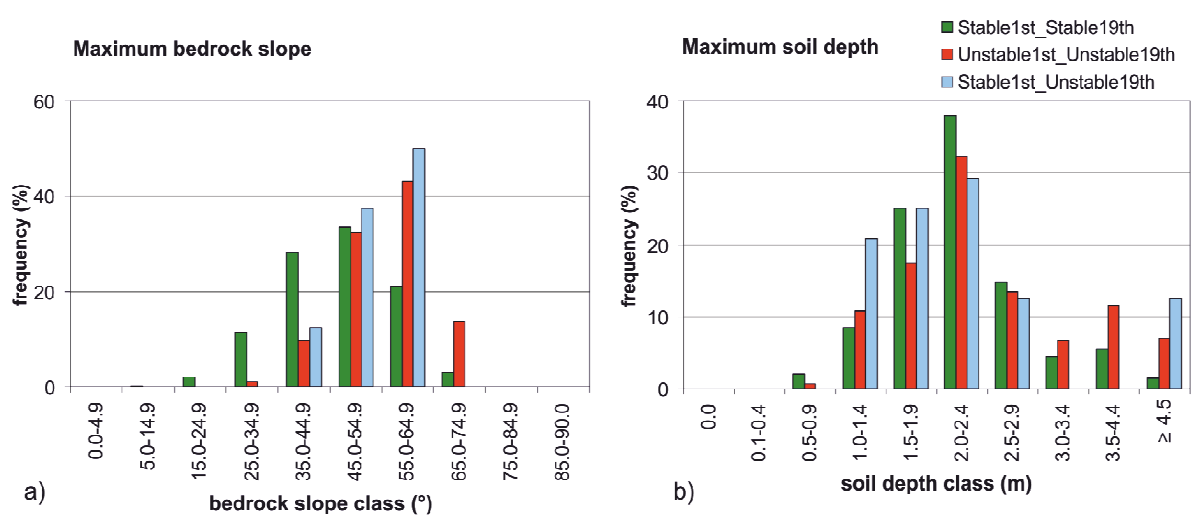

\section{A coupled \\ distributed}

hydrological-stability analysis

C. Camera et al.

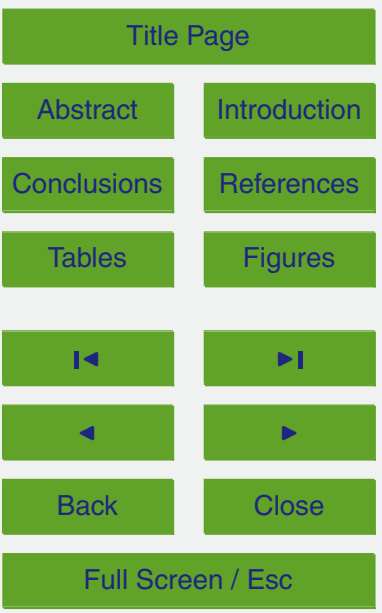

Printer-friendly Version

Fig. 10. Frequency diagram of the maximum bedrock slope (a) and maximum soil depth (b) for stable (SS), unstable (UU) and stable-unstable (SU) terraces. Values are expressed in percentages according to the total number of stable (SS), unstable (UU) and stable-unstable (SU) terraces respectively. 